\title{
2D Porphyrinic Metal-Organic Frameworks Featuring Rod-Shaped Secondary Building Units
}

\author{
Rory Elliott ${ }^{1}$, Aoife A. Ryan ${ }^{2}$, Aviral Aggarwal ${ }^{1}$, Nianyong Zhu ${ }^{1}$, Friedrich W. Steuber ${ }^{1}{ }^{\mathbb{D}}$, Mathias O. Senge ${ }^{3} \mathbb{C}$ \\ and Wolfgang Schmitt ${ }^{1, *}$ \\ 1 School of Chemistry \& AMBER Centre, Trinity College, University of Dublin, Dublin, Ireland; \\ relliot@tcd.ie (R.E.); aviralaggarwal23@gmail.com (A.A.); zhun@tcd.ie (N.Z.); steuberf@tcd.ie (F.W.S.) \\ 2 School of Chemistry, Chair of Organic Chemistry, Trinity Biomedical Science Institute, 152-160 Pearse Street, \\ Trinity College, The University of Dublin, Dublin, Ireland; ryana16@tcd.ie \\ 3 Focus Group-Molecular and Interfacial Engineering of Organic Nanosystems, Institute for Advanced \\ Study (TUM-IAS), Technical University of Munich, Lichtenberg-Str. 2a, 85748 Garching, Germany; \\ mathias.senge@tum.de \\ * Correspondence: schmittw@tcd.ie
}

check for updates

Citation: Elliott, R.; Ryan, A.A.; Aggarwal, A.; Zhu, N.; Steuber, F.W.; Senge, M.O.; Schmitt, W. 2D

Porphyrinic Metal-Organic

Frameworks Featuring Rod-Shaped Secondary Building Units. Molecules 2021, 26, 2955. https://doi.org/ $10.3390 /$ molecules26102955

Academic Editor: Constantina Papatriantafyllopoulou

Received: 1 April 2021

Accepted: 12 May 2021

Published: 16 May 2021

Publisher's Note: MDPI stays neutral with regard to jurisdictional claims in published maps and institutional affiliations.

Copyright: (c) 2021 by the authors. Licensee MDPI, Basel, Switzerland. This article is an open access article distributed under the terms and conditions of the Creative Commons Attribution (CC BY) license (https:/ / creativecommons.org/licenses/by/ $4.0 /)$.

\begin{abstract}
Metal-organic frameworks (MOFs) encompass a rapidly expanding class of materials with diverse potential applications including gas storage, molecular separation, sensing and catalysis. So-called 'rod MOFs', which comprise infinitely extended 1D secondary building units (SBUs), represent an underexplored subclass of MOF. Further, porphyrins are considered privileged ligands for MOF synthesis due to their tunable redox and photophysical properties. In this study, the $\mathrm{Cu}^{\mathrm{II}}$ complex of 5,15-bis(4-carboxyphenyl)-10,20-diphenylporphyrin $\left(\mathrm{H}_{2} \mathbf{L}-\mathrm{Cu}^{\mathrm{II}}\right.$, where $\mathrm{H}_{2}$ refers to the ligand's carboxyl H atoms) is used to prepare two new 2D porphyrinic rod MOFs PROD-1 and PROD-2. Single-crystal X-ray analysis reveals that these frameworks feature $1 \mathrm{D} \mathrm{Mn}^{\mathrm{II}}$ - or Co $\mathrm{CO}^{\mathrm{II}}$-based rod-like SBUs that are coordinated by labile solvent molecules and photoactive porphyrin moieties. Both materials were characterised using infrared (IR) spectroscopy, powder X-ray diffraction (PXRD) spectroscopy and thermogravimetric analysis (TGA). The structural attributes of PROD-1 and PROD2 render them promising materials for future photocatalytic investigations.
\end{abstract}

Keywords: metal-organic framework; MOF; 2D MOF; 2D materials; rod MOF; Porphyrin MOF; Porphyrinoids; coordination chemistry

\section{Introduction}

Over the last decades, MOFs have attracted substantial scientific attention [1,2]. Members of this emerging class of modular, metallo-supramolecular polymeric materials can be conceptualised as repeating combinations of inorganic secondary building units (SBUs or 'nodes') that are bridged by multitopic organic ligands (or 'linkers') [3]. This arrangement gives infinitely extended multidimensional framework structures with long-range order and high crystallinity [4]. As MOFs demonstrate chemical tunability and high surface areas, they are versatile materials with the potential to advance technologies to tackle several substantial scientific challenges $[5,6]$.

To date, tens of thousands of MOFs have been reported in the literature [7-11]. The vast majority of these structures, including the archetypal frameworks MOF-5 [ $\left.\mathrm{Zn}_{4} \mathrm{O}(\mathrm{BDC})_{3}\right]$ (BDC = 1,4-benzene dicarboxylate) and HKUST-1 $\left[\mathrm{Cu}_{3}(\mathrm{BTC})_{2}\left(\mathrm{H}_{2} \mathrm{O}\right)_{3}\right](\mathrm{HKUST}=\mathrm{Hong}$ Kong University of Science and Technology, BTC = benzene-1,3,5-tricarboxylate), comprise discrete SBUs [12,13]. Topologically, these frameworks can be understood by abstracting their sub-components as simple geometric shapes such as triangles, squares, tetrahedra, etc., which interconnect to yield a network structure [14,15].

The inimitable modularity and surface areas of MOF materials grants them broad applicability in areas such as gas storage, molecular separation, drug delivery, sensing, 
and spintronics [16-21]. MOFs can accommodate well-defined, physically separated redoxactive sites, which also makes them attractive compounds for catalytic applications [22-26]. Frameworks featuring open metal sites (non-coordinatively saturated inorganic nodes) or labile coordinated solvent moieties are particularly promising for catalysis, as these aspects allow substrates to bind with the metal ions of a MOF's SBU $[27,28]$. Alternatively, catalytic processes can occur at redox-active metal ions that are embedded within the linkers of certain MOFs, for example porphyrin-based MOFs [29,30]. MOFs are also prime materials for a myriad of electrochemical technologies such as photovoltaics, fuel cells, batteries and supercapacitors [31]. However, porous 3D MOFs constructed from redoxinactive linkers are typically electronically insulating, which limits their suitability for these applications $[32,33]$.

2D MOFs or coordination polymers with layered architectures are a subclass of MOF with distinctive dimensional-dependent characteristics, including exposed surface sites and good flexibility and mechanical stability [34]. The layered architectures of these MOFs can give rise to exceptional electronic, optical and magnetic properties [35-37]. Moreover, 2D MOFs often exhibit favourable conductivities, as lower dimensional systems limit charge carrier scattering [38]. Their unique attributes make layered metal-organic materials promising systems for catalysis, conductive devices, and "smart membranes" [39-41].

Among the various organic ligands used in MOF synthesis, porphyrins and metalloporphyrins are advantageous due to their unique photophysical and redox properties [30]. These tetrapyrrolic macrocycles are ubiquitous in nature, where they execute essential functions for fundamental biological processes including catalysis, photosynthesis, and gas transport [42,43]. Introducing coordinating carboxylic acid or pyridyl functional groups at a porphyrin's meso positions allows a macrocycle to be incorporated within a MOF as a rigid, functional linker [44]. In 1991, Robson and co-workers reported the first porphyrinic MOF, which was prepared in a reaction between [5,10,15,20-tetrakis(4-pyridyl)porphyrinato]palladium(II) (MTPP-Pd ${ }^{\mathrm{II}}$ ) and $\mathrm{Cd}\left(\mathrm{NO}_{3}\right)_{2} \cdot 4 \mathrm{H}_{2} \mathrm{O}$ in a mixture of boiling $\mathrm{MeOH}$ and $\mathrm{H}_{2} \mathrm{O}$. This 3D framework, formulated as $\left[\mathrm{Cd}^{\mathrm{II}}{ }_{2}\left(\mathrm{MTPP}-\mathrm{Pd}^{\mathrm{II}}\right)\left(\mathrm{NO}_{3}\right)_{4}\left(\mathrm{H}_{2} \mathrm{O}\right)_{4}\right] \cdot 5 \mathrm{H}_{2} \mathrm{O}$, features mononuclear Cd ${ }^{\mathrm{II}}$ nodes that are bridged by palladium tetrapyridyl porphyrin linkers [45]. Subsequent to the discovery of this prototypal porphyrinic framework, significantly more porphyrin-based MOFs have been developed with a wide range of potential applications such as molecular separation, light-harvesting, and photocatalysis [46-53]. The facile tunability of metalloporphyrins has expedited this effort, as simply substituting the central metal ion or $\beta$-pyrrole position of a porphyrin yields a linker that can impart improved functionality to a framework.

In contrast to MOFs constructed from finite SBUs, rod MOFs represent a subclass of frameworks with infinitely extended 1D nodes containing chains of periodically repeating metal ions linked by polytopic ligands [54-56]. Rod MOFs afford significant advantages over other MOFs, including a lower tendency to form interpenetrated networks and a higher propensity to stabilise open metal sites. Despite this, rod MOFs remain relatively underexplored in the literature $[57,58]$.

In natural light-harvesting systems, highly ordered supramolecular architectures funnel solar energy towards a reaction centre $[59,60]$. Analogously to biological systems, the regular arrays of proximally positioned $\pi$-conjugated porphyrin ligands in porphyrinic MOFs can promote long-range charge transport via networks of $\pi-\pi$ stacking interactions [61-65]. Hupp et al. recently investigated exciton migration in two porphyrinic MOFs using fluorescence quenching experiments, revealing that these frameworks facilitate long range anisotropic energy transfer over up to ca. 45 porphyrin struts [46]. This study suggests that porphyrin-based MOFs may be useful bioinspired materials for photoelectrochemical applications, for example as thin film electrode coatings within artificial photosynthetic devices [66-69]. Similarly, light-harvesting porphyrins and related metal-organic materials with favourable charge transport characteristics can be applied in dye-sensitized or perovskite solar cells to increase the efficiencies of such energy conversion devices [70-75]. 
In this study, two novel porphyrinic rod MOFs $\left[\mathrm{Mn}^{\mathrm{II}}\left(\mathrm{L}-\mathrm{Cu}^{\mathrm{II}}\right)(\mathrm{MeOH})_{2}\right] \cdot \mathrm{DEA} \cdot \mathrm{MeOH}$ $\left(\mathrm{PROD}-1, \mathrm{DEA}=(\mathrm{N}, \mathrm{N}\right.$-diethylacetamide $)$ and $\left[\mathrm{Co}^{\mathrm{II}}\left(\mathrm{L}-\mathrm{Cu}^{\mathrm{II}}\right)(\mathrm{DEA})\right] \cdot 8 \mathrm{MeOH}(\mathrm{PROD}-2)$ are reported. These compounds comprise distinct, infinitely extended rod-shaped $\mathrm{Mn}^{\mathrm{II}}$ - or $\mathrm{Co}^{\mathrm{II}}$-based SBUs that are connected by porphyrin ligands, giving rise to $2 \mathrm{D}$ sheet architectures. Both PROD-1 and PROD-2 are characterised using single-crystal X-ray diffraction, infrared (IR) spectroscopy, powder X-ray diffraction (PXRD) spectroscopy and thermogravimetric analysis (TGA). Ultimately, due to the presence of specific structural motifs in these frameworks, some potential applications of these materials are discussed.

\section{Results and Discussion}

\subsection{Synthesis of Metalloporphyrin Rod MOFs}

The ditopic porphyrin 5,15-bis(4-carboxyphenyl)-10,20-diphenylporphyrin $\left(\mathrm{H}_{4} \mathrm{~L}\right)$ was selected to synthesise MOFs endowed with the unique electronic and photophysical properties of porphyrins. This choice was rationalised due to the rich chemical diversity of MOFs constructed from other, more rudimentary dicarboxylate linear linkers, and because at the time of writing only two MOFs reported in the Cambridge Structural Database (CSD, Version 5.41) contain this underexplored porphyrin [76-82]. Additionally, the central cavity of $\mathrm{H}_{4} \mathrm{~L}$ can accommodate an array of metal ions, which facilitates further tuning of frameworks constructed using this linker [83,84]. Considering the promising light-harvesting [85] and catalytic [86] properties of comparable $\mathrm{Cu}^{\mathrm{II}}$ metalloporphyrin complexes, and the low cost and toxicity of Copper, [5,15-bis(4-carboxyphenyl)-10,20diphenylporphyrinato]copper(II) $\left(\mathrm{H}_{2} \mathrm{~L}-\mathrm{Cu}^{\mathrm{II}}\right)$ was prepared in moderate yield (see experimental for details) [87,88].

$\mathrm{H}_{2} \mathrm{~L}-\mathrm{Cu}^{\mathrm{II}}$ was used to prepare two 2D MOFs $\left[\mathrm{Mn}^{\mathrm{II}}\left(\mathrm{L}-\mathrm{Cu}^{\mathrm{II}}\right)(\mathrm{MeOH})_{2}\right] \cdot \mathrm{DEA} \cdot \mathrm{MeOH}$ (PROD-1) and $\left[\mathrm{Co}^{\mathrm{II}}\left(\mathrm{L}-\mathrm{Cu}^{\mathrm{II}}\right)(\mathrm{DEA})\right] \cdot 8 \mathrm{MeOH}(\mathrm{PROD}-2)$ with $1 \mathrm{D} \mathrm{Mn}^{\mathrm{II}}$ - or Co $\mathrm{Co}^{\mathrm{II}}$-based SBUs, respectively (Figure 1). PROD-1 was prepared by heating $\mathrm{H}_{2} \mathrm{~L}-\mathrm{Cu}^{\mathrm{II}}$ and $\mathrm{MnCl}_{2} \cdot 2 \mathrm{H}_{2} \mathrm{O}$ in a mixture of DEA and $\mathrm{MeOH}$ to $120{ }^{\circ} \mathrm{C}$ for four days in a Teflon-lined stainless-steel autoclave. Slowly cooling this reaction mixture to room temperature afforded the formation of uniform, rod-shaped, crimson crystals of PROD-1. Similarly, PROD-2 was synthesised by heating $\mathrm{H}_{2} \mathrm{~L}-\mathrm{Cu}$ II and $\mathrm{CoCl}_{2}$ in a mixture of $\mathrm{DEA}, \mathrm{MeOH}$ and acetic acid $(\mathrm{AcOH})$ under solvothermal conditions. After four days, this reaction mixture was slowly cooled to ambient temperature, resulting in the formation of red, plate-shaped crystals of PROD- 2 . Both products PROD-1 and PROD-2 form reproducibly, in good yields and were of suitable quality for analysis using single-crystal X-ray diffraction.

\subsection{Crystal Structure of $\left[\mathrm{Mn}^{I I}\left(\mathrm{~L}-\mathrm{Cu} \mathrm{U}^{\mathrm{II}}\right)(\mathrm{MeOH})_{2}\right] \cdot \mathrm{DEA} \cdot \mathrm{MeOH}(\mathrm{PROD}-1)$}

The single-crystal X-ray structure of PROD-1 was solved in the triclinic space group $P \overline{1}$. This analysis was hampered due to twinned crystals and weak diffraction. However, the data allowed us to establish the structure's connectivity. PROD-1 comprises stacking 2D sheets, containing 1D rod-like $\mathrm{Mn}^{\mathrm{II}}$-based SBUs that extend infinitely in the direction of the crystallographic $a$-axis (Figure 2a). The SBUs of PROD-1 are each linked to two other identical inorganic nodes by ditopic $\left(\mathrm{L}-\mathrm{Cu}^{\mathrm{II}}\right)^{2-}$ ligands (Figure $2 \mathrm{~b}$ ). This connectivity gives rise to $2 \mathrm{D}$ sheets which extend with the crystallographic $a c$-plane, and in which rodshaped SBUs stack in parallel with one another (Figure 2c,d). Neighbouring interconnected inorganic nodes within the 2D sheets are separated by ca. $22 \AA$.

The asymmetric unit of PROD- 1 contains one $\mathrm{Mn}^{\mathrm{II}}$ centre, one $\left(\mathrm{L}-\mathrm{Cu}^{\mathrm{II}}\right)^{2-}$ ligand, two coordinated $\mathrm{MeOH}$ solvent moieties, and constitutional DEA and $\mathrm{MeOH}$ solvent molecules which locate between the small channels that extend between the MOF's 2D layers. The SBU of PROD-1 comprises an infinite chain of octahedrally coordinated $\mathrm{Mn}^{\mathrm{II}}$ centres, each of which connect to two adjacent metal ions through four bridging carboxylate moieties that derive from four $\left(\mathrm{L}-\mathrm{Cu}^{\mathrm{II}}\right)^{2-}$ linkers. The interatomic distance between two $\mathrm{Mn}^{\mathrm{II}}$ centres within the 1D SBU is ca. $4.6 \AA$. 


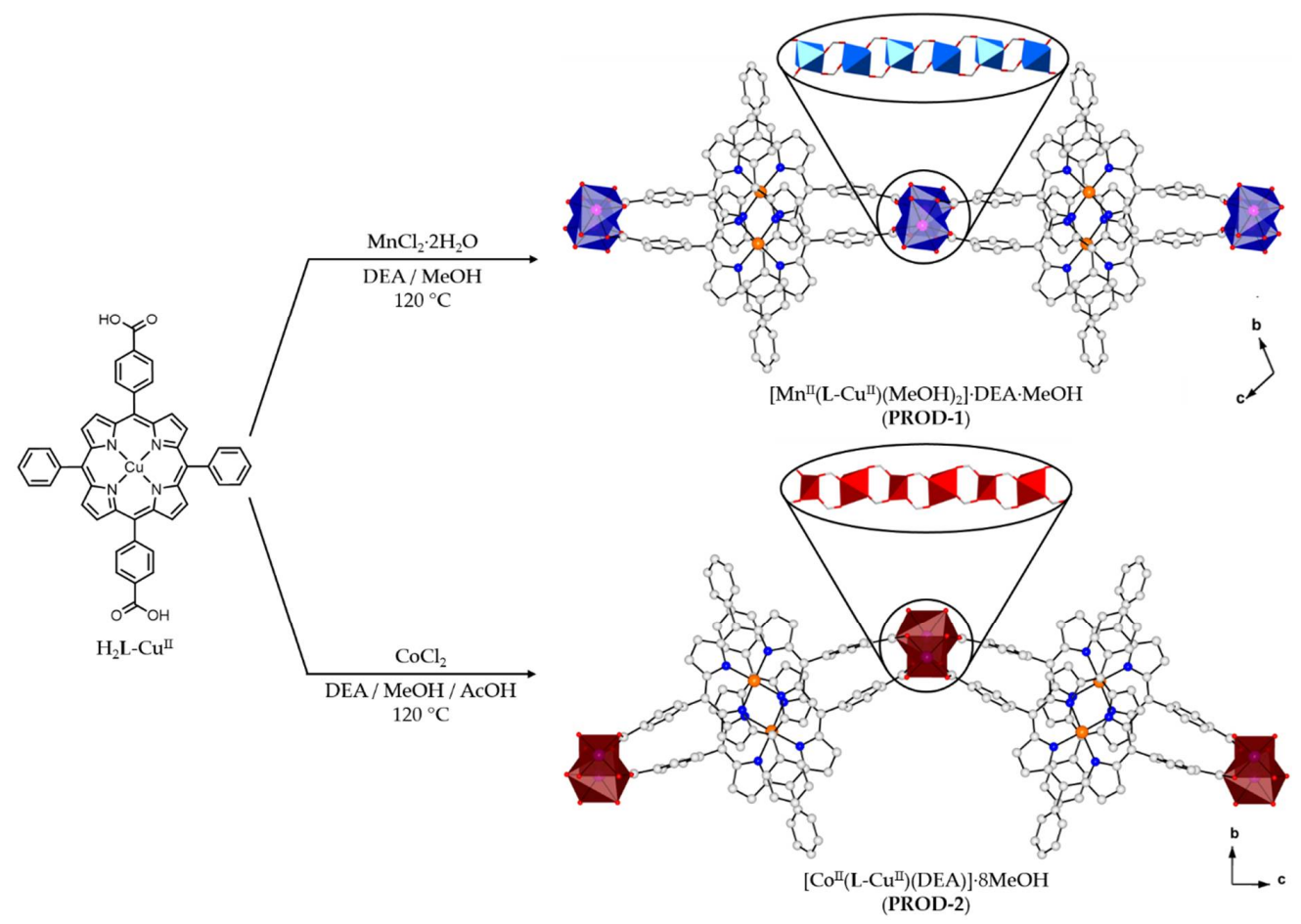

Figure 1. $\mathrm{H}_{2} \mathbf{L}-\mathrm{Cu}^{\mathrm{II}}$ was used to prepare two 2D porphyrinic rod MOFs, PROD-1 and PROD-2. Insets show the $1 D$ chain SBUs of PROD-1 and PROD-2. H atoms and solvent molecules are omitted for clarity. Colour scheme: $\mathrm{C}$ white, $\mathrm{N}$ blue, $\mathrm{O}$ red, $\mathrm{Cu}$ orange, Mn pink, Co violet. $\mathrm{Mn}^{\mathrm{II}}$ and $\mathrm{Co}^{\mathrm{II}}$ coordination environments are represented by blue and red polyhedra, respectively.

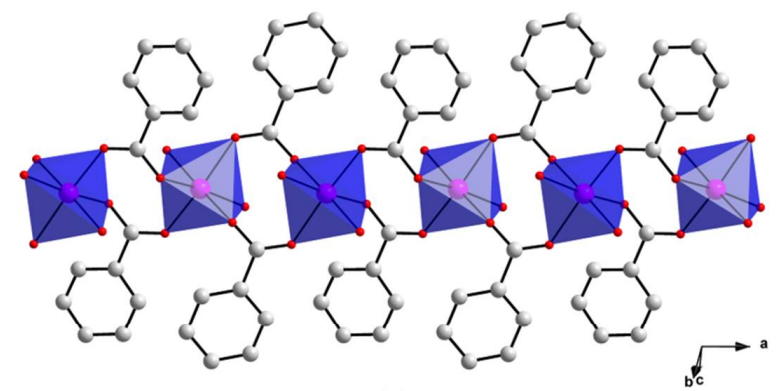

(a)

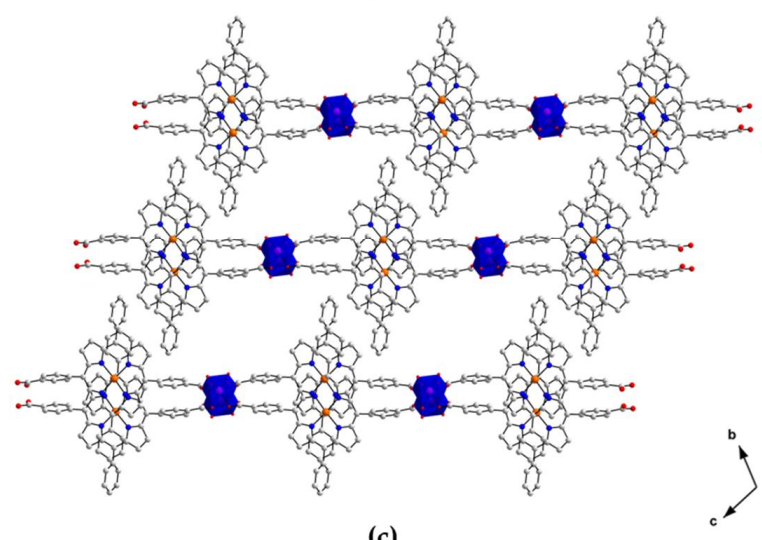

(c)

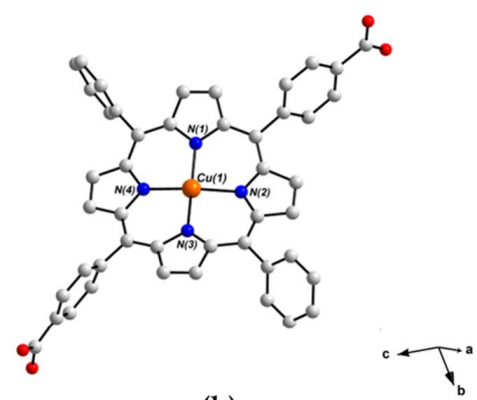

(b)

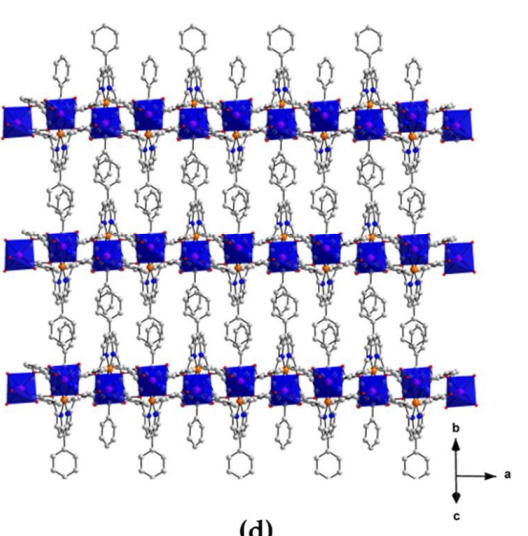

(d)

Figure 2. View of the structure of PROD-1 in the crystal, showing (a) the MOF's rod-shaped SBU which comprises an infinite 1D chain of octahedrally coordinated $\mathrm{Mn}^{\mathrm{II}}$ ions bridged by the syn-syn coordinating carboxylate functionalities of $\left(\mathbf{L}-\mathrm{Cu}^{\mathrm{II}}\right)^{2-}$ linkers, $(\mathbf{b})$ the linear metalloporphyrin ligand $\left(\mathbf{L}-\mathrm{Cu}^{\mathrm{II}}\right)^{2-}$ and $(\mathbf{c}, \mathbf{d})$ the packing arrangement of PROD-1, highlighting the MOF's layered architecture. $\mathrm{H}$ atoms and solvent molecules are omitted for clarity. Colour scheme: $\mathrm{C}$ white, $\mathrm{N}$ blue, $\mathrm{O}$ red, $\mathrm{Mn}$ pink, $\mathrm{Cu}$ orange. $\mathrm{Mn}^{\mathrm{II}}$ coordination environments are shown as blue polyhedra. 
The binding environment of the $\mathrm{Mn}^{\mathrm{II}}$ centre $\mathrm{Mn}(1)$ within the $1 \mathrm{D}$ SBU of PROD-1 is shown in Figure 3a. The coordination sphere of $\mathrm{Mn}(1)$ comprises four O-donors $\mathrm{O}(1), \mathrm{O}(3)$, $\mathrm{O}(5)$ and $\mathrm{O}(6)$ from four distinct syn-syn bridging, $\mu_{2}-\eta^{1}: \eta^{1}$ binding carboxylate functionalities and two $\mathrm{O}$-donors $\mathrm{O}(2)$ and $\mathrm{O}(4)$ which derive from two 'cis'-coordinated $\mathrm{MeOH}$ solvent moieties. The bond distances between $\mathrm{Mn}(1)$ and each of the four carboxylate O-donors are within the range 2.15-2.17 $\AA$, whereas the distances from the $\mathrm{Mn}^{\mathrm{II}}$ ion and the more labile, monodentate $\mathrm{MeOH}$ moieties range between $2.21 \AA$ and $2.23 \AA$. The bond angles surrounding $\mathrm{Mn}(1)$ render its coordination geometry a slightly distorted octahedron, and are consistent with values reported for comparable $\mathrm{Mn}^{\mathrm{II}}$-carboxylate complexes in the literature $[89,90]$.

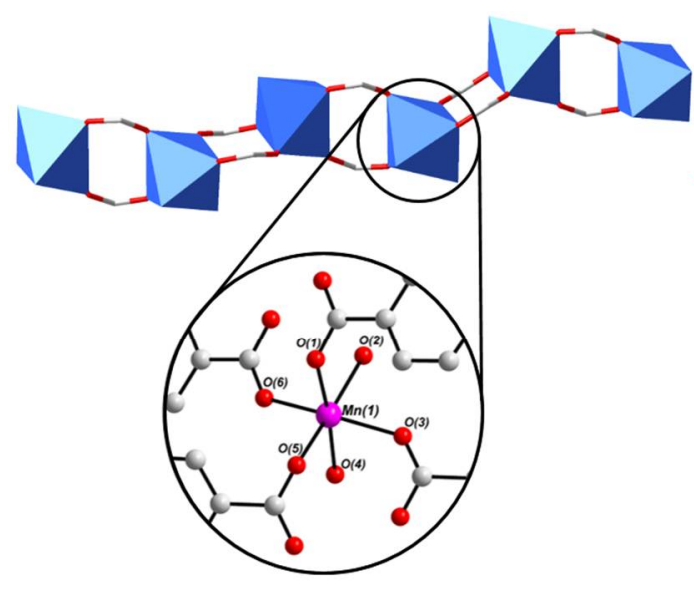

(a)

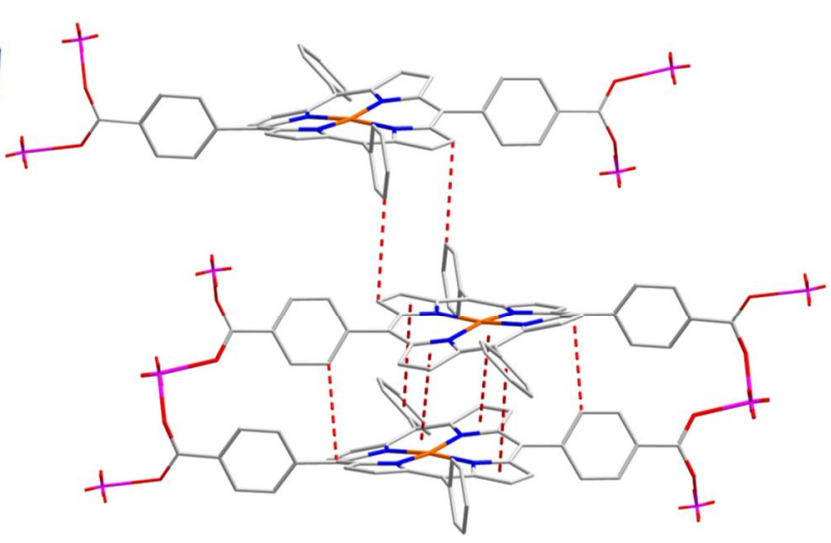

(b)

Figure 3. (a) The coordination environment of the $\mathrm{Mn}^{\mathrm{II}}$ ion $\mathrm{Mn}(1)$ within the $1 \mathrm{D}$ chain SBU of PROD-1, which includes two $\mathrm{MeOH}$ solvent-derived $\mathrm{O}$-donors $\mathrm{O}(2)$ and $\mathrm{O}(4)$, and (b) a wireframe representation highlighting $\pi-\pi$ stacking interactions which stabilize PROD-1. H atoms have been omitted for clarity. Colour scheme: $\mathrm{C}$ white, $\mathrm{N}$ blue, $\mathrm{O}$ red, $\mathrm{Cu}$ orange, Mn pink. Blue polyhedra represent $\mathrm{Mn}^{\mathrm{II}}$ coordination environments. $\pi-\pi$ interactions are highlighted using dashed red lines.

An extensive network of $\pi-\pi$ stacking interactions stabilise this structure, some of which are shown in Figure $3 b$. For example, T-shaped intersheet $\pi-\pi$ stacking interactions between the meso-phenyl and tetrapyrrole moieties of $\left(\mathrm{L}-\mathrm{Cu}{ }^{\mathrm{II}}\right)^{2-}$ linkers, and paralleldisplaced intrasheet $\pi-\pi$ stacking interactions between adjacent metalloporphyrins are highlighted. These supramolecular interactions propagate in parallel with the crystallographic $b$-axis and extend the 2D network into a 3D framework. The distances between $\pi-\pi$ interacting moieties in PROD-1 are within the range of 3.4-3.8 $\AA$, which is consistent with $\pi-\pi$ stacking interactions reported in the literature [91,92].

The porphyrin linkers within PROD-1 adopt saddle-shaped configurations and have staggered meso-functionalities [93]. The bond angles between 'trans'-coordinated pyrrolic $\mathrm{N}$-donors deviate from the ideal square planer angle by up to ca. $8^{\circ}$, whilst the dihedral angles between meso-carboxyaryl and meso-phenyl functional groups are ca. $27(1)^{\circ}$ and $43(1)^{\circ}$, respectively. This configuration facilitates stabilisation of the structure through $\pi-\pi$ stacking interactions.

$\left(\mathrm{L}-\mathrm{Cu}^{\mathrm{II}}\right)^{2-}$ is deprotonated at both of its carboxylic acid binding sites, giving the linker a charge of -2 . As one ligand is present per $\mathrm{Mn}^{\mathrm{II}}$ centre in the crystal structure, the overall charge of PROD-1 is balanced. Bond valence sum analysis (BVSA) calculations confirmed the oxidation states of all metal ions in PROD-1.

In the crystal structure of PROD-1, 2D sheets pack densely and porphyrin moieties interdigitate between neighbouring layers. Small, interlayer channels filled with constitutional solvent molecules and infinite 1D zig-zag $\mathrm{Mn}^{\mathrm{II}}$ chains extend in parallel with the crystallographic $a$-axis. The average distance between two adjacent $2 \mathrm{D}$ sheets in PROD-1 is ca. $15 \AA$. The solvent-accessible void volume of PROD-1 was calculated as $250 \AA^{3}$ (ac- 
counting for $10.4 \%$ of the unit cell volume) using the CCDC-mercury program with a probe radius of $1.2 \AA$ and a grid spacing of $0.7 \AA$ [94].

\subsection{Crystal Structure of $\left[C O^{I I}\left(L-C u^{I I}\right)(D E A)\right] \cdot 8 \mathrm{MeOH}(P R O D-2)$}

The single-crystal X-ray structure of PROD-2 was solved in the monoclinic space group $P 2 / c$, revealing that this MOF and PROD- 1 are structurally alike, as both of these frameworks feature 2-connected rod-shaped SBUs (Figure 4a) and ditopic $\left(\mathrm{L}-\mathrm{Cu}^{\mathrm{II}}\right)^{2-}$ ligands (Figure 4b). Unlike PROD-1, however, the infinite 1D rod-like node of PROD-2 comprises periodically repeating, alternating tetrahedral and octahedral $\mathrm{Co}^{\mathrm{II}}$ centres. Interconnected, infinitely extended $\mathrm{Co}^{\mathrm{II}}$ chains and porphyrin linkers form 2D layers that extend in parallel with the crystallographic ac-plane and undulate in the crystallographic $b$-directions due to the alternating coordination geometries of this MOF's metal ions. The 2D layers of PROD-2 of stack on top of one another and interdigitate, giving rise to the corrugated sheet structure shown in Figure 4c.

The asymmetric unit of PROD-2 contains two distinct $\mathrm{Co}^{\mathrm{II}}$ centres $\mathrm{Co}(1)$ and $\mathrm{Co}(2)$ which locate at two-fold rotational axes and have a crystallographic occupancy of $\frac{1}{2}$, one doubly deprotonated $\left(\mathrm{L}-\mathrm{Cu}^{\mathrm{II}}\right)^{2-}$ ligand and one coordinated DEA solvent molecule. Disordered constitutional solvent molecules which could not be refined in the crystal structure of PROD-2 were masked using the Platon-Squeeze routine [95]. The interatomic distance between $\mathrm{Co}(1)$ and $\mathrm{Co}(2)$ is $4.5020(14) \AA$, and the distance between two connected rod-shaped nodes is ca. $22 \AA$.

The binding environments of $\mathrm{Co}(1)$ and $\mathrm{Co}(2)$ within the zig-zag chain SBU of PROD-2 are depicted in Figure 5a. These ions adopt distorted octahedral and distorted tetrahedral coordination geometries, and are each coordinated by four O-donors from four bridging, $\mu_{2}-\eta^{1}: \eta^{1}$ binding carboxylate moieties that link adjacent $\mathrm{Co}^{\mathrm{II}}$ centres into infinite $1 \mathrm{D}$ chains. In addition two O-donors, $\mathrm{O}(5)$ and $\mathrm{O}\left(5^{\prime}\right)$, derived from two labile, 'cis'-coordinated DEA solvent moieties are contained within the coordination sphere of $\operatorname{Co}(1)$. The bond distances surrounding the octahedral $\mathrm{Co}^{\mathrm{II}}$ centre $\mathrm{Co}(1)$ are within the range of 2.2626(5)-2.3850(5) $\AA$, whilst the bond distances around the tetrahedrally coordinated $\mathrm{Co}^{\mathrm{II}}$ ion $\mathrm{Co}(2)$ range between 1.9484(4) A and 1.9604(5) A. The bond distances and angles surrounding Co(1) and $\mathrm{Co}(2)$ are consistent with the values reported for other tetrahedral and octahedral $\mathrm{Co}^{\mathrm{II}}$ carboxylate complexes in the literature [96-98].

As in PROD-1, the porphyrin ligand of PROD-2 adopts a saddle-shaped configuration which facilitates intrasheet $\pi-\pi$ stacking interactions between neighbouring $\left(\mathrm{L}^{-} \mathrm{Cu}^{\mathrm{II}}\right)^{2-}$ moieties (Figure 5b). The extent to which the linkers of PROD-2 are distorted is marginally less than those of PROD-1. Dihedral angles between meso-substituted phenyl, and carboxyaryl functionalities in PROD-2 vary by up to $33.0^{\circ}$, which promotes intersheet T-shaped $\pi-\pi$ interactions between nearby porphyrins. The distances between $\pi-\pi$ stacking moieties in PROD-2 fall within the range of 3.5-3.8 $\AA$ [92].

The porphyrin linker in PROD-2 is doubly deprotonated, and thus has a charge of -2 . This charge is balanced by two crystallographically $\frac{1}{2}$ occupied $\mathrm{Co}^{\mathrm{II}}$ ions $\mathrm{Co}(1)$ and $\mathrm{Co}(2)$, giving PROD-2 a net charge of 0 . BVSA calculations confirmed the assignment of the +2 oxidation state of $\mathrm{Co}(1), \mathrm{Co}(2)$ and $\mathrm{Cu}(1)$. Undulant interdigitated 2D sheets pack densely in the crystal structure, giving PROD-2 its characteristic corrugated conformation. Small, interlayer solvent-accessible channels propagate in parallel with the crystallographic $a$-axis, constituting a solvent-accessible void volume of $452 \AA^{3}$ which corresponds to $8.9 \%$ of the MOF's unit cell (calculated using CCDC-mercury with a probe radius and grid spacing of 1.2 and $0.7 \AA$, respectively) [94]. 


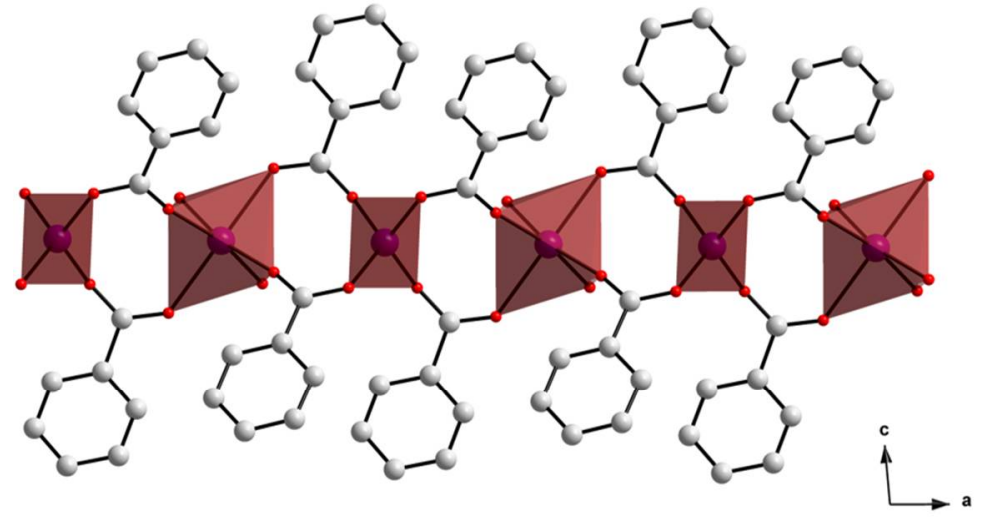

(a)

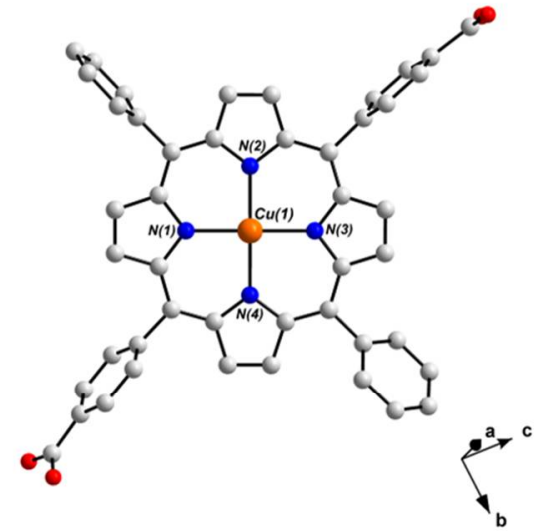

(b)

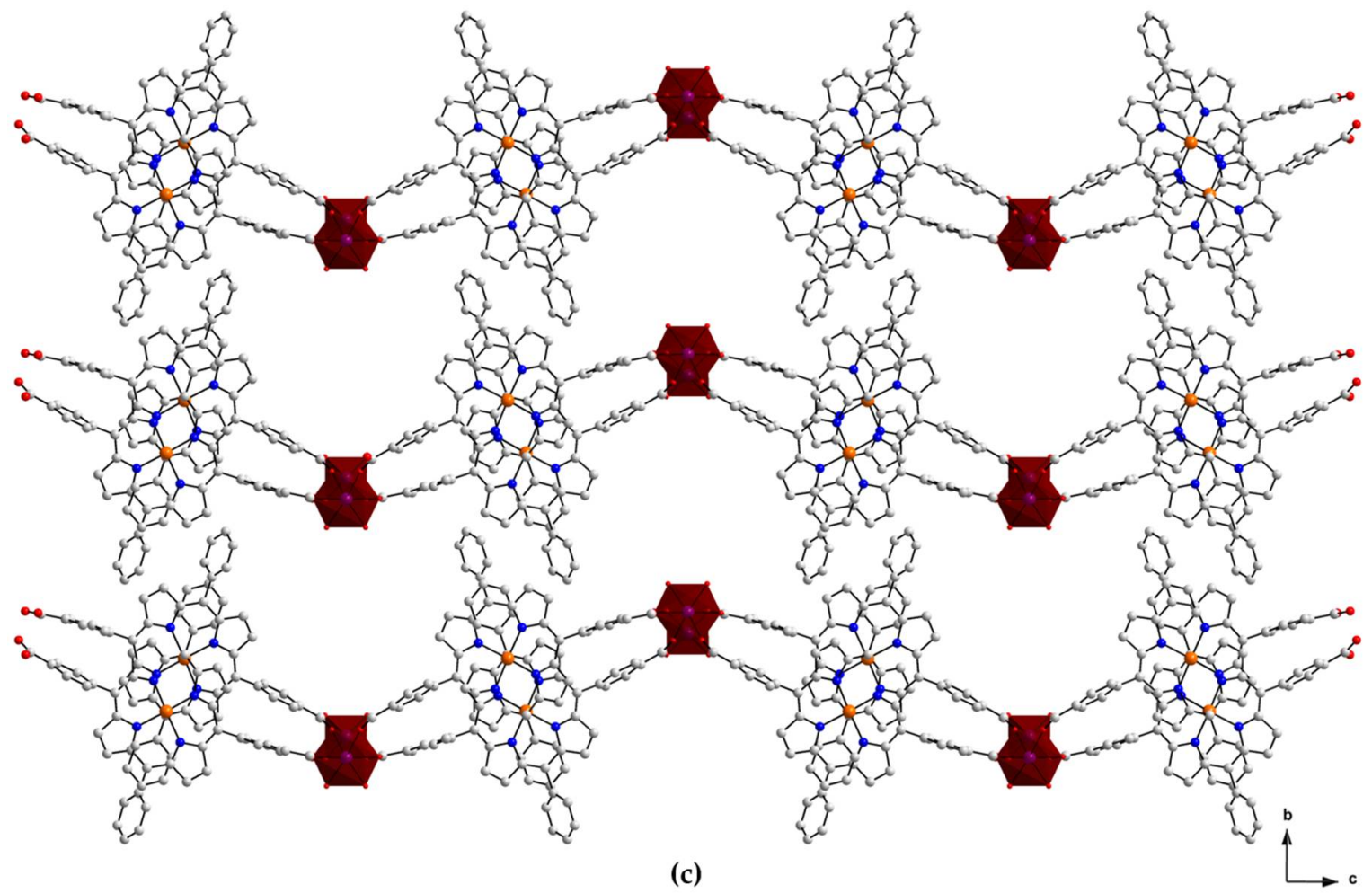

Figure 4. View of the structure of PROD-2 in the crystal, highlighting (a) the framework's 1D rod-shaped SBU comprising an infinite chain of alternating tetrahedrally and octahedrally coordinated $\mathrm{Co}^{\mathrm{II}}$ ions, (b) the linker $\left(\mathrm{L}-\mathrm{Cu}^{\mathrm{II}}\right)^{2-}$ and (c) the packing arrangement of PROD-2. Hydrogen atoms and solvent molecules are omitted for the purpose of clarity. Colour scheme: $\mathrm{C}$ white, $\mathrm{O}$ red, $\mathrm{N}$ blue, $\mathrm{Cu}$ orange. Red polyhedra represent $\mathrm{Co}{ }^{\mathrm{II}}$ coordination environments.

PROD-1 and PROD-2 crystallize under comparable reaction conditions and share several structural similarities. Both structures inhabit an intersection in chemical space between 2D, rod and porphyrin-based MOFs, which confers a constellation of characteristics making them desirable for various future technologies. For instance, PROD-1 and PROD-2 contain well-ordered arrays of metalloporphyrin linkers and are stabilised by $\pi-\pi$ stacking interactions [99]. This could give rise to light-harvesting or energy transfer properties that are advantageous for photo- or electrochemical applications including photovoltaics or photocatalysis [100]. PROD-1 and PROD-2 are particularly promising for catalytic applications, as their layered architectures, 1D channels and rod-shaped SBUs support high concentrations of exposed labile coordination solvent sites. Moreover, the presence of photoactive porphyrin linkers that coordinate directly to potentially redox-active $\mathrm{Mn}^{\mathrm{II}}$ and $\mathrm{Co}^{\mathrm{II}}$ centres in PROD-1 and PROD-2 could give rise to photocatalytic activity. Finally, 
the tunable and fully noble metal-free nature of these compounds is advantageous, as it facilitates facile modifications and lowers the investment costs associated with these MOFs.

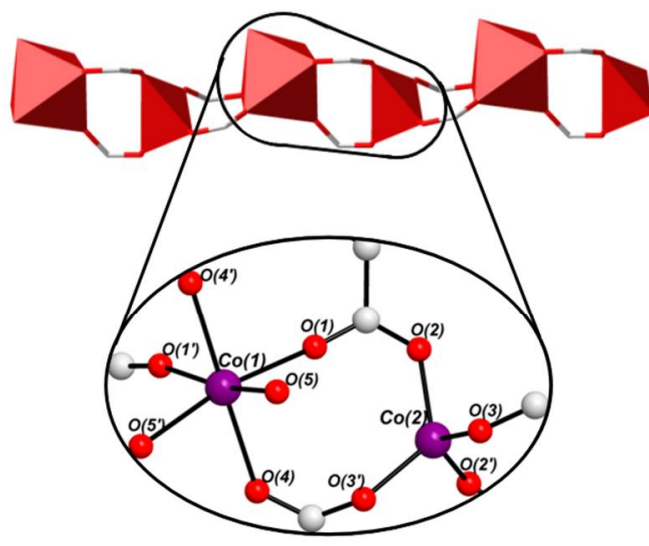

(a)

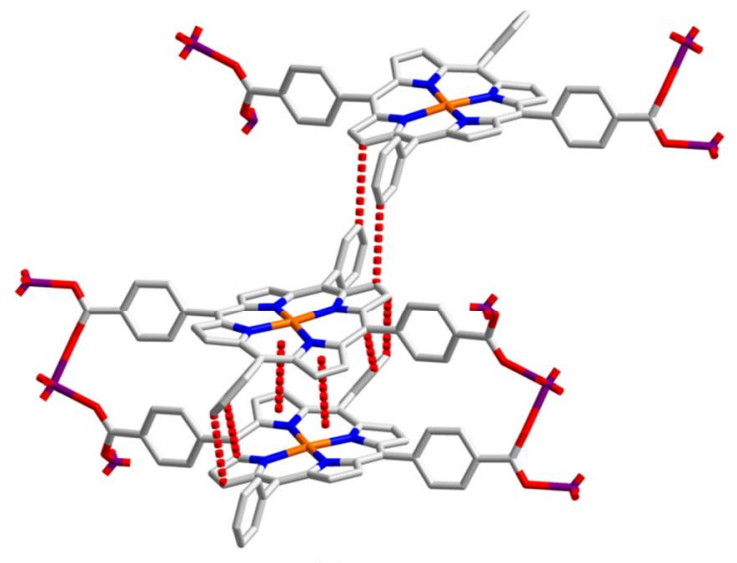

(b)

Figure 5. (a) Coordination environments of the Co $\mathrm{CO}^{\mathrm{II}}$ ions within PROD-2's 1D SBU, featuring two DEA-derived O-donors $\mathrm{O}(5)$ and $\mathrm{O}\left(5^{\prime}\right)$, and (b) selected $\pi-\pi$ stacking interactions that stabilize PROD-2. H atoms are omitted for clarity. Colour scheme: $\mathrm{C}$ white, $\mathrm{N}$ blue, $\mathrm{O}$ red, $\mathrm{Cu}$ orange, Co violet. Red polyhedra represent $\mathrm{Co}^{\mathrm{II}}$ coordination spheres and dashed red lines show $\pi-\pi$ stacking.

\subsection{Physicochemical Characterisation of PROD-1 E PROD-2}

The IR spectra of PROD-1 (Figure S1) and PROD-2 (Figure S2) exhibit characteristic signals confirming the presence of the porphyrin ligand $\left(\mathrm{L}-\mathrm{Cu}{ }^{\mathrm{II}}\right)^{2-}$. For example, several signals centred around $3000 \mathrm{~cm}^{-1}$ are attributed to aromatic $\mathrm{C}-\mathrm{H}$ stretching vibrations of the metalloporphyrin linkers in both MOFs. In addition, bands at ca. 1540 and $1380 \mathrm{~cm}^{-1}$ are assigned to asymmetric and symmetric stretching vibrational modes, respectively, of the $\mu^{2}-\eta^{1}: \eta^{1}$ bridging carboxylate moieties of PROD-1 and PROD-2 [101]. Weak signals at around $1280 \mathrm{~cm}^{-1}$ can be attributed to $\mathrm{C}-\mathrm{N}$ stretching vibrations of the MOF's (L$\left.\mathrm{Cu}^{\mathrm{II}}\right)^{2-}$ linkers. Furthermore, sharp signals at 1001 and $994 \mathrm{~cm}^{-1}$ may arise due to inplane vibrations (ring breathing) of the porphyrin macrocycles of PROD-1 and PROD-2, respectively [102]. Finally, bands at ca. $1600 \mathrm{~cm}^{-1}$ can be attributed to $\mathrm{C}=\mathrm{O}$ stretching vibrations from the coordinated and constitutional DEA solvent molecules within PROD-1 and PROD-2 [103].

The thermal stabilities of PROD-1 and PROD-2 were investigated using TGA by heating these compounds from $30-800{ }^{\circ} \mathrm{C}$ under $\mathrm{N}_{2}$. The TGA trace of PROD-1 (Figure S3) reveals that when heated from $25-80^{\circ} \mathrm{C}$, the sample undergoes a weight loss of $2.5 \%$ which can be attributed to the loss of one constitutional $\mathrm{MeOH}$ solvent molecule (calculated: $3.1 \%$ ). It is likely that some solvent of crystallisation was lost from the framework prior to this analysis. An additional mass loss of $5.2 \%$ is observed as the sample is heated from $80-300^{\circ} \mathrm{C}$, which can be accounted for by the loss of a DEA coordination solvent molecule from PROD-1 (calculated: $6.2 \%$ ). Further heating of the sample from $300-455{ }^{\circ} \mathrm{C}$ was associated with a further mass loss of $11.0 \%$, which results from the loss of one constitutional DEA solvent molecule from PROD-1 (calculated: 11.2\%). Two additional thermogravimetric steps are observed between $455-540{ }^{\circ} \mathrm{C}$ and above $540{ }^{\circ} \mathrm{C}$, which can be attributed to the decomposition of the MOF's organic components and to the formation of metal oxide species, respectively.

The TGA trace of PROD-2 (Figure S4) shows that the structure degrades in several distinct thermogravimetric steps. As the sample is heated from $30-105^{\circ} \mathrm{C}$ a mass loss of $20.6 \%$ is observed. This decrease in mass can be attributed to the loss eight constitutional $\mathrm{MeOH}$ solvent molecules from PROD-2 (calculated: 21.5\%). When PROD-2 is heated further from $105-360{ }^{\circ} \mathrm{C}$, a weight loss of $9.3 \%$ is observed. This weight loss is associated with the loss of one coordinated DEA molecule from PROD-2 (calculated: 9.7\%). Heating 
the sample from $360-500{ }^{\circ} \mathrm{C}$ is associated with the decomposition of the framework's organic ligands. Finally, the formation of metal oxide species occurs as the sample is heated above $500{ }^{\circ} \mathrm{C}$. These TGA experiments reveal that both PROD-1 and PROD-2 are thermally stable up to ca. $350{ }^{\circ} \mathrm{C}$, as the MOF's porphyrin linkers start to decompose above this temperature. As the disordered constitutional solvent molecules of PROD-2 could not be modelled crystallographically, interpretation of these data enabled the assignment of this compound's molecular formula $\left[\mathrm{Co}^{\mathrm{II}}\left(\mathrm{L}-\mathrm{Cu}^{\mathrm{II}}\right)(\mathrm{DEA})\right] \cdot 8 \mathrm{MeOH}$. Upon desolvation, both PROD-1 and PROD-2, do not take up significant quantities of $\mathrm{N}_{2}$.

PXRD patterns of PROD-1 (Figure S5) and PROD-2 (Figure S6) were measured and compared with simulated PXRD patterns that were calculated from the corresponding compound's single-crystal X-ray diffraction data to evaluate the phase purity of the prepared samples. The experimentally obtained PXRD pattern of PROD-1 agrees well with its simulated pattern. Discrepancies for PROD-2 may result from structural changes due to rapid sample desolvation prior to or during PXRD analysis and crystal orientation effects.

\section{Materials and Methods}

\subsection{Reagents \& Analytical Methods}

All chemicals and solvents were of reagent grade and used as received without further purification unless otherwise stated. Single-crystal X-ray structural analyses were performed on a Bruker SMART APEX CCD diffractometer with a $\mathrm{Cu}-\mathrm{K} \alpha \mathrm{X}$-ray source $(\lambda=1.54184 \AA)$. The omega scan method was used to collect either a full sphere or hemisphere of data for each crystal with a detector to crystal distance of either 5 or $6 \mathrm{~cm}$ at temperatures of 100 or $215 \mathrm{~K}$. Data were collected, processed, and corrected for Lorentz and polarisation effects using SMART [104] and SAINT-PLUS [105] programs. The structures were solved using direct methods with the SHELXTL [106] software package. All non-hydrogen atoms were refined anisotropically. Hydrogen atom positions were assigned using a riding model with appropriately fixed isotropic thermal parameters. Solventaccessible void volumes were calculated using the 'voids' tool in Mercury (CCDC) using a probe radius of $1.2 \AA$ and a grid spacing of $0.7 \AA$ [94]. Crystallographic information files for PROD-1 and PROD-2 can be obtained free of charge from the Cambridge Crystallographic Data Centre via www.ccdc.cam.ac.uk/data_request/cif using the accession identifiers CCDC-2073036 and CCDC-2065629, respectively. For the structural refinement of PROD-1, the DFIX constraint was applied to the bonds of an identified coordinated $\mathrm{N}, \mathrm{N}$-diethylacetamide (DEA) molecule due its disorder in the structure. Common C-C, $\mathrm{C}-\mathrm{N}$ and $\mathrm{C}-\mathrm{O}$ bond lengths, characteristic for DEA molecules were applied. Additionally, a FLAT command, restraints some of the atoms of the DEA molecule to lie in a common plane. The approach resulted in convergence upon least-square refinements. Further DEA and $\mathrm{MeOH}$ solvent molecules were located in the voids of the structure and their occupancies were refined to achieve convergence. The occupancies $<1$ are caused by solvent loss during mounting and data collection or disorder of the solvent molecules whereby parts of the disordered positions could not be located. The twin character of the crystals of PROD-2 was noted during the crystallographic data collection. A careful selection of reflection spots was required prior to indexing and integration. The HKLF5 command was applied to the refinement. This approach allowed us to solve the structure. Finally, the Platon twin routine was applied to further resolve the degree of twinning, leading to the reported quality values. The Platon-Squeeze routine was applied due to the diffuse electron density that results from highly disordered solvent molecules located in the voids of the structure. The solvent-accessible void volume accounts to $1143 \AA^{3}$ and 272 electrons. This electron contribution stems from solvent molecules, i.e., methanol which was used in the synthesis. The TGA analysis is consistent with the crystallographic data. Based on this analysis, 8 constitutional $\mathrm{MeOH}$ molecules were assigned to the structure.

IR spectra were recorded using a PerkinElmer Spectrum One FT-IR spectrometer equipped with a universal ATR sampling accessory. Data were collected and processed using Spectrum v5.0.1 (2002 PerkinElmer Instrument LLC) software. The scan rate was 
16 scans per second with a resolution of $4 \mathrm{~cm}^{-1}$ in the range $4000-650 \mathrm{~cm}^{-1}$. Standard abbreviations were used to describe signal intensities: s, strong; $\mathrm{m}$, medium; $\mathrm{w}$, weak; $\mathrm{br}$, broad. Thermogravimetric analysis (TGA) data were collected using a simultaneous SDT thermal analyser at a heating rate of $5{ }^{\circ} \mathrm{C} \mathrm{min}^{-1}$ under a $\mathrm{N}_{2}$ atmosphere $\left(\mathrm{N}_{2}\right.$ flow rate $=0.06 \mathrm{~L} \mathrm{~min}^{-1}$ ). PXRD data were collected at room temperature with a Bruker D2 Phaser diffractometer equipped with a $\mathrm{CuK} \alpha \mathrm{X}$-ray source. Simulated PXRD patterns were calculated from the single-crystal X-ray data of PROD-1 and PROD-2 using the CCDCMercury program (Cambridge, UK) [94]. ${ }^{1} \mathrm{H}$ NMR spectra were recorded on a Bruker DPX 400 spectrometer operating at $400.13 \mathrm{MHz}$. Samples were analysed in deuterated solvents that are listed for each spectrum. Standard abbreviations are used for spectral assignments: $\mathrm{s}$, singlet; $\mathrm{d}$, doublet; $\mathrm{t}$, triplet; $\mathrm{m}$, multiplet; br, broad; J, coupling constant. UV-Vis spectra were recorded in the range $300-800 \mathrm{~nm}$ on a Cary Scan spectrophotometer at $20^{\circ} \mathrm{C}$ using disposable cells with a path length of $1 \mathrm{~cm}$.

\subsection{Synthesis of the Porphyrin Ligand $\mathrm{H}_{2} \mathrm{~L}-\mathrm{Cu}{ }^{\mathrm{II}}$}

The dicarboxylic acid porphyrin $\mathrm{H}_{2} \mathrm{~L}-\mathrm{Cu}^{\mathrm{II}}$ was prepared in four steps, beginning with the synthesis of 5-(4-carbomethoxyphenyl)dipyrromethane, according to adapted procedures described by Lindsey et al. [107] and Meindl et al. [108] Under an inert atmosphere and while shielding from light, trifluoroacetic acid (TFA, $0.23 \mathrm{~mL} 0.343 \mathrm{mmol}$ ) was added to a solution of methyl-4-formyl benzoate $(5.00 \mathrm{~g}, 30.4 \mathrm{mmol})$ in freshly distilled pyrrole $(150 \mathrm{~mL}, 2.162 \mathrm{~mol})$, before stirring the solution for $3 \mathrm{~h}$. NaOH $(3.60 \mathrm{~g}, 0.090 \mathrm{~mol})$ was then added, and the reaction was stirred for a further hour. Following this, the reaction mixture was filtered before concentrating the filtrate by evaporating the solvent under reduced pressure, while excess pyrrole was recovered for later use. The crude product obtained was subsequently purified by silica gel column chromatography using a mixture of hexane, dichloromethane (DCM), ethyl acetate and triethylamine (TEA) in a ratio of 4:2:1:0.05 ( $\mathrm{vol} / \mathrm{vol})$ as the eluting solvent before washing with cold ethyl acetate yielding 5-(4-carbomethoxyphenyl)dipyrromethane as a white powder. Yield: $4.26 \mathrm{~g}(50 \%) .{ }^{1} \mathrm{H}$ $\operatorname{NMR}\left(400 \mathrm{MHz}, \mathrm{CD}_{3} \mathrm{CN}\right): \delta(\mathrm{ppm})=8.94(\mathrm{~m}, 2 \mathrm{H}, \mathrm{NH}), 7.92(\mathrm{~m}, 2 \mathrm{H}, \operatorname{aryl}-\mathrm{H}), 7.32(\mathrm{~m}, 2 \mathrm{H}$, aryl-H), $6.66(\mathrm{~m}, 2 \mathrm{H}$, pyrrole-H), $6.02(\mathrm{~m}, 2 \mathrm{H}$, pyrrole- $\mathrm{H}), 5.77(\mathrm{~m}, 2 \mathrm{H}$, pyrrole- $\mathrm{H}), 5.52(\mathrm{~s}$, $1 \mathrm{H}, \mathrm{CH}), 3.85\left(\mathrm{~s}, 3 \mathrm{H}, \mathrm{CH}_{3}\right)$.

Next, under an inert atmosphere and darkness, benzaldehyde $(3.6 \mathrm{~mL}, 35.3 \mathrm{mmol})$ was added to a solution of 5-(4-carbomethoxyphenyl)dipyrromethane $(9.60 \mathrm{~g}, 34.5 \mathrm{mmol})$ in dry DCM (3.3 L). To this solution, TFA $(6.6 \mathrm{~mL})$ was added dropwise over $1 \mathrm{~min}$. The reaction mixture was then stirred for $3 \mathrm{~h}$ before adding $p$-chloranil $(12.48 \mathrm{~g}, 50.7 \mathrm{mmol})$ and stirring overnight. Following this, TEA $(6.6 \mathrm{~mL})$ was added to quench the reaction before removing the solvent under reduced pressure. The crude product was then dry loaded onto silica and purified using silica gel column chromatography with $\mathrm{CH}_{3} \mathrm{Cl}$ as the eluting solvent. A purple powder consisting of several different methoxy ester-substituted porphyrins was obtained as the second purple band after 5,10,15,20-tetraphenylporphyrin. This powder was then dry loaded on to silica and purified using silica gel column chromatography with DCM and hexane in a ratio of 2:1 (vol/vol) as the eluent, giving the desired diester porphyrin in the third purple band. Evaporation of the solvent under reduced pressure yielded 5,15-bis(4-carbomethoxyphenyl)-10,20-diphenylporphyrin as a purple powder. Yield: $0.6 \mathrm{~g}(17 \%) .{ }^{1} \mathrm{H}$ NMR $\left(400, \mathrm{MHz} \mathrm{CDCl}_{3}\right): \delta(\mathrm{ppm})=8.80(\mathrm{~m}, 4 \mathrm{H}$, pyrrole- $\mathrm{H}), 8.75(\mathrm{~m}, 4 \mathrm{H}$, pyrrole- $\mathrm{H}), 8.45(\mathrm{~d}, 4 \mathrm{H}$, benzyl- $\mathrm{H}, J=9.2 \mathrm{~Hz}), 8.28(\mathrm{~d}, 4 \mathrm{H}$, benzyl$\mathrm{H}, J=6.9 \mathrm{~Hz}), 8.20(\mathrm{~d}, 4 \mathrm{H}, \operatorname{aryl}-\mathrm{H}, J=9.2 \mathrm{~Hz}), 7.78(\mathrm{~m}, 6 \mathrm{H}$, aryl- $\mathrm{H}), 4.12\left(\mathrm{~s}, 6 \mathrm{H}, \mathrm{CH}_{3}\right),-2.78$ (br, s, $2 \mathrm{H}$, pyrrole-H). UV-Vis (DMF): $\lambda_{\max } / \mathrm{nm}\left(\varepsilon / \mathrm{L} \mathrm{mol}^{-1} \mathrm{~cm}^{-1}\right)=415\left(1.8 \times 10^{5}\right.$, Soret band, $\left.\pi-\pi^{*}\right), 513\left(9.0 \times 10^{3}\right.$, Q band, $\left.\pi-\pi^{*}\right), 546\left(4.0 \times 10^{3}\right.$, Q band, $\left.\pi-\pi^{*}\right), 590\left(3.4 \times 10^{3}\right.$, Q band, $\left.\pi-\pi^{*}\right), 645\left(2.9 \times 10^{3}\right.$, Q band, $\left.\pi-\pi^{*}\right)$. MS (MALDI-TOF): Found $m / z=730.2417$. Calculated $m / z=730.2580$ for $\left[\mathrm{C}_{48} \mathrm{H}_{34} \mathrm{~N}_{4} \mathrm{O}_{4}\right]$.

Following this, 5,15-bis(4-methoxycarbonylphenyl)-10,20-diphenylporphyrin (600 mg, $0.821 \mathrm{mmol})$ was dissolved in $\mathrm{CHCl}_{3}(100 \mathrm{~mL})$ and heated to $70{ }^{\circ} \mathrm{C}$. $\mathrm{Cu}(\mathrm{OAc})_{2}$ monohydrate $(1.624 \mathrm{~g}, 8.210 \mathrm{mmol})$ dissolved in $\mathrm{MeOH}(10 \mathrm{~mL})$ was then added to the heated 
solution and the reaction was stirred at $70{ }^{\circ} \mathrm{C}$ for $3 \mathrm{~h}$. Upon complete consumption of the starting material, monitored via TLC analysis $\left(\mathrm{CH}_{2} \mathrm{Cl}_{2}\right.$ : hexanes, $\left.2: 1, v / v\right)$, the reaction mixture was washed with saturated $\mathrm{NaHCO}_{3}$, water and brine $(2 \times 100 \mathrm{~mL}$ each), extracting with $\mathrm{CH}_{2} \mathrm{Cl}_{2}$. The organic extracts were dried over $\mathrm{Na}_{2} \mathrm{SO}_{4}$, filtered and the solvents were removed in vacuo. The red residue (5,15-bis(4-methoxycarbonylphenyl)-10,20diphenylporphyrinato\}copper(II) \} was used without further purification in the ester hydrolysis step. (5,15-Bis(4-methoxycarbonylphenyl)-10,20-diphenylporphyrinato)copper(II) (approximately $600 \mathrm{mg}$ ) was dissolved in THF $(50 \mathrm{~mL})$ and to this solution $\mathrm{KOH}(12 \mathrm{~g}$ in $50 \mathrm{~mL} \mathrm{H}_{2} \mathrm{O}$ ) was added. The reaction mixture was heated to $80{ }^{\circ} \mathrm{C}$ and was stirred at this temperature for $18 \mathrm{~h}$. Upon complete consumption of the starting material, the reaction mixture was cooled to ambient temperature before acidification to $\mathrm{pH} 6$ using $1 \mathrm{M} \mathrm{HCl}$. The product was extracted using $\mathrm{CH}_{2} \mathrm{Cl}_{2}$ and the organic extracts were combined, and the solvents were removed in vacuo. The red residue was triturated with $\mathrm{CHCl}_{3}$ and filtered to give a red solid which was subsequently transferred to a $250 \mathrm{~mL} \mathrm{RBF}$, suspended in $\mathrm{CHCl}_{3}$ and the solvent was removed in vacuo to yield a red residue (600 $\mathrm{mg}, 0.785 \mathrm{mmol}$, 96\%). Mp >300 ${ }^{\circ} \mathrm{C} ; \mathrm{R}_{\mathrm{f}}\left(\mathrm{CH}_{2} \mathrm{Cl}_{2}\right.$ : hexane: MeOH 1:1:0.02 v/v/v): 0.63; UV-vis (MeOH): $\lambda_{\max }(\log \varepsilon)=412(5.35), 538(4.02) \mathrm{nm}$; HRMS (MALDI): $m / z=764.2849$ calculated for $\mathrm{C}_{46} \mathrm{H}_{28} \mathrm{~N}_{4} \mathrm{O}_{4} \mathrm{Cu}$ : found; 763.1432 .

\subsection{Synthesis of $\left[\mathrm{Mn}^{I I}\left(\mathrm{~L}-\mathrm{Cu} \mathrm{u}^{I I}\right)(\mathrm{MeOH})_{2}\right] \cdot \mathrm{DEA} \cdot \mathrm{MeOH}(\mathrm{PROD}-1)$}

$\mathrm{H}_{2} \mathrm{~L}-\mathrm{Cu}^{\mathrm{II}}(15.0 \mathrm{mg}, 19.7 \mu \mathrm{mol})$ and $\mathrm{MnCl}_{2} \cdot 2 \mathrm{H}_{2} \mathrm{O}(3.20 \mathrm{mg}, 19.8 \mu \mathrm{mol})$ were dissolved in $N, N$-diethylacetamide (DEA) $(11.0 \mathrm{~mL})$ and $\mathrm{MeOH}(6.0 \mathrm{~mL})$ by sonicating the mixture for $30 \mathrm{~min}$. The resulting solution was then transferred into a Teflon-lined stainless-steel autoclave and heated to $120^{\circ} \mathrm{C}$ for 4 days, before slowly cooling to ambient temperature. This afforded the formation of crimson, rod-shaped crystals of PROD-1 which were of suitable quality for analysis using single-crystal X-ray diffraction. Yield: $4.78 \mathrm{mg}(24 \%)$. FT-IR: $v_{\max }=2978(\mathrm{br}, \mathrm{w}), 1607(\mathrm{~m}), 1581$ (s), $1536(\mathrm{~m}), 1487(\mathrm{w}), 1366$ (vs), 1282 (w), $1210(\mathrm{w}), 1175(\mathrm{w}), 1012(\mathrm{w}), 1001(\mathrm{~s}), 831(\mathrm{w}), 796(\mathrm{~s}), 697(\mathrm{~s}) \mathrm{cm}^{-1}$.

\subsection{Synthesis of $\left[C O^{I I}\left(L-C u^{I I}\right)(D E A)\right] \cdot 8 \mathrm{MeOH}(P R O D-2)$}

$\mathrm{H}_{2} \mathrm{~L}-\mathrm{Cu} \mathrm{II}^{\mathrm{II}}(1.2 \mathrm{mg}, 1.56 \mu \mathrm{mol})$ and $\mathrm{CoCl}_{2}(1.5 \mathrm{mg}, 11.5 \mu \mathrm{mol})$ were dissolved in $N, N$ diethylacetamide (DEA) $(1.0 \mathrm{~mL})$ and $\mathrm{MeOH}(0.5 \mathrm{~mL})$ by sonicating for $30 \mathrm{~min}$. Following this, a drop of acetic acid was added to the reaction mixture and the solution was transferred into a small glass vial, which was subsequently placed inside a sealed Teflon-lined stainlesssteel autoclave and heated to $120^{\circ} \mathrm{C}$ for 4 days. Slow cooling of the reaction mixture to room temperature over $24 \mathrm{~h}$ afforded the formation of red, plate-shaped crystals of PROD-2 which were suitable for single-crystal X-ray diffraction studies. Yield: $0.6 \mathrm{mg}$ (39\%). FT-IR: $v_{\max }=2969$ (vbr, m), $1594(\mathrm{~s}), 1548(\mathrm{~m}), 1373(\mathrm{~s}), 1334(\mathrm{~s}), 1276(\mathrm{~m}), 1204(\mathrm{w}), 1181(\mathrm{w}), 1067$ (w), $994(\mathrm{~s}), 832(\mathrm{w}), 797(\mathrm{~s}), 773(\mathrm{~s}), 699(\mathrm{~s}) \mathrm{cm}^{-1}$.

\section{Conclusions}

In conclusion, we report two new 2D porphyrinic MOFs with rod-shaped SBUs, PROD-1 and PROD-2, which are rare examples of frameworks featuring the underexplored linker $\mathrm{H}_{2} \mathrm{~L}-\mathrm{Cu}{ }^{\mathrm{II}}$. Single-crystal X-ray diffraction studies show that the contrasting coordination geometries found within the MOFs' 1D metal chain SBUs give rise to either planar or corrugated sheet configurations. PROD-1 and PROD-2 are thermally stable up to ca. $350{ }^{\circ} \mathrm{C}$ and exhibit extensive networks of $\pi-\pi$ stacking interactions. The present structures are intriguing supramolecular substances which span several subclasses including 2D, porphyrinic and rod MOFs. Their unique attributes render them hopeful compounds for a wide range of future applications, and their structural relationship to Nature's paragon $\mathrm{H}_{2} \mathrm{O}$ splitting Mn complex in PS II, suggests that PROD-1 and PROD-2 might ultimately find use within bioinspired artificial photosynthetic systems [109]. 
Supplementary Materials: Electronic supporting information containing crystallographic tables and physicochemical characterisation data for PROD-1 and PROD-2, and crystallographic information files (CIFs) are available online.

Author Contributions: Conceptualisation, W.S.; MOF syntheses and structural characterisations, R.E. and A.A.; X-ray crystallographic analysis, F.W.S. and N.Z; preparation of porphyrin precursor ligands, A.A.R. and M.O.S.; writing—original draft preparation, R.E.; writing-review and editing, R.E., M.O.S. and W.S.; visualisation, R.E.; supervision, W.S.; project administration, W.S.; funding acquisition, W.S. and M.O.S. All authors have read and agreed to the published version of the manuscript.

Funding: This research was funded by Science Foundation Ireland (SFI IvP 13/IA/1896) and the European Research Council (CoG 2014-647719). This work was prepared with the support of the Technical University of Munich-Institute for Advanced Study through a Hans Fischer Senior Fellowship.

Institutional Review Board Statement: Not applicable.

Informed Consent Statement: Not applicable.

Data Availability Statement: Crystallographic information files for PROD-1 and PROD-2 can be obtained free of charge from the Cambridge Crystallographic Data Centre via www.ccdc.cam.ac.uk/ data_request/cif using the accession identifiers CCDC-2073036 and CCDC-2065629, respectively.

Conflicts of Interest: The authors declare no conflict of interest.

Sample Availability: Samples of the compounds are not available from the authors.

\section{References}

1. Furukawa, H.; Cordova, K.E.; O’Keeffe, M.; Yaghi, O.M. The Chemistry and Applications of Metal-Organic Frameworks. Science 2013, 341, 1230444. [CrossRef] [PubMed]

2. Cheong, V.F.; Moh, P.Y. Recent Advancement in Metal-Organic Framework: Synthesis, Activation, Functionalisation, and Bulk Production. Mater. Sci. Technol. 2018, 34, 1025-1045. [CrossRef]

3. Eddaoudi, M.; Jaheon, K.; Nathaniel, R.; David, V.; Joseph, W.; O’Keeffe, M.; Yaghi, O.M. Systematic Design of Pore Size and Functionality in Isoreticular MOFs and Their Application in Methane Storage. Science 2002, 295, 469-472. [CrossRef]

4. Eddaoudi, M.; Moler, D.B.; Li, H.; Chen, B.; Reineke, T.M.; O'Keeffe, M.; Yaghi, O.M. Modular Chemistry: Secondary Building Units as a Basis for the Design of Highly Porous and Robust Metal-Organic Carboxylate Frameworks. Acc. Chem. Res. 2001, 34, 319-330. [CrossRef]

5. Silva, P.; Vilela, S.M.F.; Tomé, J.P.C.; Almeida Paz, F.A. Multifunctional Metal-Organic Frameworks: From Academia to Industrial Applications. Chem. Soc. Rev. 2015, 44, 6774-6803. [CrossRef] [PubMed]

6. Bilal, M.; Adeel, M.; Rasheed, T.; Iqbal, H.M.N. Multifunctional Metal-Organic Frameworks-Based Biocatalytic Platforms: Recent Developments and Future Prospects. J. Mater. Res. Technol. 2019, 8, 2359-2371. [CrossRef]

7. Kalmutzki, M.J.; Hanikel, N.; Yaghi, O.M. Secondary Building Units as the Turning Point in the Development of the Reticular Chemistry of MOFs. Sci. Adv. 2018, 4, 9180. [CrossRef] [PubMed]

8. Martins, L.; Macreadie, L.K.; Sensharma, D.; Vaesen, S.; Zhang, X.; Gough, J.J.; O'Doherty, M.; Zhu, N.-Y.; Rüther, M.; O’Brien, J.E.; et al. Light-Harvesting, 3rd Generation $\mathrm{Ru}^{\mathrm{II}} / \mathrm{Co}^{\mathrm{II}} \mathrm{MOF}$ with a Large, Tubular Channel Aperture. Chem. Commun. 2019, 55, 5013-5016. [CrossRef]

9. Sensharma, D.; Zhu, N.; Tandon, S.; Vaesen, S.; Watson, G.W.; Schmitt, W. Flexible Metal-Organic Frameworks for LightSwitchable $\mathrm{CO}_{2}$ Sorption Using an Auxiliary Ligand Strategy. Inorg. Chem. 2019, 58, 9766-9772. [CrossRef]

10. Tobin, G.; Comby, S.; Zhu, N.; Clérac, R.; Gunnlaugsson, T.; Schmitt, W. Towards Multifunctional Lanthanide-Based MetalOrganic Frameworks. Chem. Commun. 2015, 51, 13313-13316. [CrossRef]

11. Hawes, C.S.; Ó'Máille, G.M.; Byrne, K.; Schmitt, W.; Gunnlaugsson, T. Tetraarylpyrrolo[3,2-b]Pyrroles as Versatile and Responsive Fluorescent Linkers in Metal-Organic Frameworks. Dalton Trans. 2018, 47, 10080-10092. [CrossRef] [PubMed]

12. Li, H.; Eddaoudi, M.; O'Keeffe, M.; Yaghi, O.M. Design and Synthesis of an Exceptionally Stable and Highly Porous Metal-Organic Framework. Nature 1999, 402, 276-279. [CrossRef]

13. Chui, S.S.-Y.; Lo, S.M.-F.; Charmant, J.P.H.; Orpen, A.G.; Williams, I.D. A Chemically Functionalizable Nanoporous Material [Cu $\left(\mathrm{Cu}_{3}\right.$ (TM)2 $\left.\left(\mathrm{H}_{2} \mathrm{O}\right) 3\right]$ N. Science 1999, 283, 1148-1150. [CrossRef]

14. Kim, D.; Liu, X.; Lah, M.S. Topology Analysis of Metal-Organic Frameworks Based on Metal-Organic Polyhedra as Secondary or Tertiary Building Units. Inorg. Chem. Front. 2015, 2, 336-360. [CrossRef]

15. Britt, D.; Tranchemontagne, D.; Yaghi, O.M. Metal-Organic Frameworks with High Capacity and Selectivity for Harmful Gases. Proc. Natl. Acad. Sci. USA 2008, 105, 11623-11627. [CrossRef] 
16. Kuppler, R.J.; Timmons, D.J.; Fang, Q.-R.; Li, J.-R.; Makal, T.A.; Young, M.D.; Yuan, D.; Zhao, D.; Zhuang, W.; Zhou, H.-C. Potential Applications of Metal-Organic Frameworks. Coord. Chem. Rev. 2009, 253, 3042-3066. [CrossRef]

17. Aulakh, D.; Pyser, J.B.; Zhang, X.; Yakovenko, A.A.; Dunbar, K.R.; Wriedt, M. Metal-Organic Frameworks as Platforms for the Controlled Nanostructuring of Single-Molecule Magnets. J. Am. Chem. Soc. 2015, 137, 9254-9257. [CrossRef]

18. Rowsell, J.L.C.; Yaghi, O.M. Strategies for Hydrogen Storage in Metal-Organic Frameworks. Angew. Chem. Int. Ed. 2005, 44, 4670-4679. [CrossRef] [PubMed]

19. Li, J.-R.; Kuppler, R.J.; Zhou, H.-C. Selective Gas Adsorption and Separation in Metal-Organic Frameworks. Chem. Soc. Rev. 2009, 38, 1477-1504. [CrossRef]

20. Lee, C.Y.; Farha, O.K.; Hong, B.J.; Sarjeant, A.A.; Nguyen, S.T.; Hupp, J.T. Light-Harvesting Metal-Organic Frameworks (MOFs): Efficient Strut-to-Strut Energy Transfer in Bodipy and Porphyrin-Based MOFs. J. Am. Chem. Soc. 2011, 133, 15858-15861. [CrossRef] [PubMed]

21. Sensharma, D.; Vaesen, S.; Healy, C.; Hartmann, J.; Kathalikkattil, A.C.; Wix, P.; Steuber, F.; Zhu, N.; Schmitt, W. CO 2 Adsorption in SIFSIX-14-Cu-i: High Performance, Inflected Isotherms, and Water-Triggered Release via Reversible Structural Transformation. Eur. J. Inorg. Chem. 2018, 1993-1997. [CrossRef]

22. Kitagawa, S.; Kitaura, R.; Noro, S. Functional Porous Coordination Polymers. Angew. Chem. Int. Ed. 2004, 43, 2334-2375. [CrossRef] [PubMed]

23. Liu, J.; Chen, L.; Cui, H.; Zhang, J.; Zhang, L.; Su, C.-Y. Applications of Metal-Organic Frameworks in Heterogeneous Supramolecular Catalysis. Chem. Soc. Rev. 2014, 43, 6011-6061. [CrossRef] [PubMed]

24. Corma, A.; García, H.; Llabrés i Xamena, F.X. Engineering Metal Organic Frameworks for Heterogeneous Catalysis. Chem. Rev. 2010, 110, 4606-4655. [CrossRef] [PubMed]

25. Farrusseng, D.; Aguado, S.; Pinel, C. Metal-Organic Frameworks: Opportunities for Catalysis. Angew. Chem. Int. Ed. 2009, 48, 7502-7513. [CrossRef]

26. Fujita, M.; Kwon, Y.J.; Washizu, S.; Ogura, K. Preparation, Clathration Ability, and Catalysis of a Two-Dimensional Square Network Material Composed of Cadmium(II) and 4,4'-Bipyridine. J. Am. Chem. Soc. 1994, 116, 1151-1152. [CrossRef]

27. Mohamed, M.H.; Yang, Y.; Li, L.; Zhang, S.; Ruffley, J.P.; Jarvi, A.G.; Saxena, S.; Veser, G.; Johnson, J.K.; Rosi, N.L. Designing Open Metal Sites in Metal-Organic Frameworks for Paraffin/Olefin Separations. J. Am. Chem. Soc. 2019, 141, 13003-13007. [CrossRef]

28. Li, B.; Chrzanowski, M.; Zhang, Y.; Ma, S. Applications of Metal-Organic Frameworks Featuring Multi-Functional Sites. Coord. Chem. Rev. 2016, 307, 106-129. [CrossRef]

29. Rogge, S.M.J.; Bavykina, A.; Hajek, J.; Garcia, H.; Olivos-Suarez, A.I.; Sepúlveda-Escribano, A.; Vimont, A.; Clet, G.; Bazin, P.; Kapteijn, F.; et al. Metal-Organic and Covalent Organic Frameworks as Single-Site Catalysts. Chem. Soc. Rev. 2017, 46, 3134-3184. [CrossRef]

30. Pereira, C.; Simões, M.; Tomé, J.; Almeida Paz, F. Porphyrin-Based Metal-Organic Frameworks as Heterogeneous Catalysts in Oxidation Reactions. Molecules 2016, 21, 1348. [CrossRef]

31. Baumann, A.E.; Burns, D.A.; Liu, B.; Thoi, V.S. Metal-Organic Framework Functionalization and Design Strategies for Advanced Electrochemical Energy Storage Devices. Commun. Chem. 2019, 2, 86. [CrossRef]

32. Sun, L.; Campbell, M.G.; Dincă, M. Electrically Conductive Porous Metal-Organic Frameworks. Angew. Chem. Int. Ed. 2016, 55, 3566-3579. [CrossRef] [PubMed]

33. Gordillo, M.A.; Saha, S. Strategies to Improve Electrical and Ionic Conductivities of Metal-Organic Frameworks. Comment. Inorg. Chem. 2020, 40, 86-106. [CrossRef]

34. Liu, W.; Yin, R.; Xu, X.; Zhang, L.; Shi, W.; Cao, X. Structural Engineering of Low-Dimensional Metal-Organic Frameworks: Synthesis, Properties, and Applications. Adv. Sci. 2019, 6, 1802373. [CrossRef] [PubMed]

35. Ashworth, D.J.; Foster, J.A. Metal-Organic Framework Nanosheets (MONs): A New Dimension in Materials Chemistry. J. Mater. Chem. A 2018, 6, 16292-16307. [CrossRef]

36. Nam, K.W.; Park, S.S.; dos Reis, R.; Dravid, V.P.; Kim, H.; Mirkin, C.A.; Stoddart, J.F. Conductive 2D Metal-Organic Framework for High-Performance Cathodes in Aqueous Rechargeable Zinc Batteries. Nat. Commun. 2019, 10, 4948. [CrossRef] [PubMed]

37. Zhu, H.; Liu, D. The Synthetic Strategies of Metal-Organic Framework Membranes, Films and 2D MOFs and Their Applications in Devices. J. Mater. Chem. A 2019, 7, 21004-21035. [CrossRef]

38. Majee, A.K.; Kommini, A.; Aksamija, Z. Electronic Transport and Thermopower in 2D and 3D Heterostructures-A Theory Perspective. Ann. Phys. 2019, 531, 1800510. [CrossRef]

39. Ko, M.; Mendecki, L.; Mirica, K.A. Conductive Two-Dimensional Metal-Organic Frameworks as Multifunctional Materials. Chem. Commun. 2018, 54, 7873-7891. [CrossRef] [PubMed]

40. Hu, X.; Chen, P.; Zhang, C.; Wang, Z.; Wang, C. Energy Transfer on a Two-Dimensional Antenna Enhances the Photocatalytic Activity of $\mathrm{CO}_{2}$ Reduction by Metal-Organic Layers. Chem. Commun. 2019, 55, 9657-9660. [CrossRef]

41. Fujimoto, J.; Hayashi, S.; Kainuma, H.; Manseki, K.; Udagawa, T.; Miyaji, H. Supramolecular Light-Harvesting Antennas of Metal-Coordinated Bis(8-Hydroxyquinoline)-Substituted Porphyrin Networks. Chem. Asian J. 2019, 14, 2567-2572. [CrossRef]

42. Smykalla, L.; Mende, C.; Fronk, M.; Siles, P.F.; Hietschold, M.; Salvan, G.; Zahn, D.R.T.; Schmidt, O.G.; Rüffer, T.; Lang, H. (Metallo)Porphyrins for Potential Materials Science Applications. Beilstein J. Nanotechnol. 2017, 8, 1786-1800. [CrossRef]

43. Senge, M.O.; MacGowan, S.A.; O'Brien, J.M. Conformational Control of Cofactors in Nature-The Influence of Protein-Induced Macrocycle Distortion on the Biological Function of Tetrapyrroles. Chem. Commun. 2015, 51, 17031-17063. [CrossRef] 
44. Gao, W.-Y.; Chrzanowski, M.; Ma, S. Metal-Metalloporphyrin Frameworks: A Resurging Class of Functional Materials. Chem. Soc. Rev. 2014, 43, 5841-5866. [CrossRef] [PubMed]

45. Abrahams, B.F.; Hoskins, B.F.; Robson, R. A New Type of Infinite 3D Polymeric Network Containing 4-Connected, PeripherallyLinked Metalloporphyrin Building Blocks. J. Am. Chem. Soc. 1991, 113, 3606-3607. [CrossRef]

46. Son, H.-J.; Jin, S.; Patwardhan, S.; Wezenberg, S.J.; Jeong, N.C.; So, M.; Wilmer, C.E.; Sarjeant, A.A.; Schatz, G.C.; Snurr, R.Q.; et al. Light-Harvesting and Ultrafast Energy Migration in Porphyrin-Based Metal-Organic Frameworks. J. Am. Chem. Soc. 2013, 135, 862-869. [CrossRef] [PubMed]

47. Kosal, M.E.; Chou, J.-H.; Wilson, S.R.; Suslick, K.S. A Functional Zeolite Analogue Assembled from Metalloporphyrins. Nat. Mater. 2002, 1, 118-121. [CrossRef] [PubMed]

48. Guo, Z.; Chen, B. Recent Developments in Metal-Metalloporphyrin Frameworks. Dalton Trans. 2015, 44, 14574-14583. [CrossRef]

49. Xiao, Y.; Guo, W.; Chen, H.; Li, H.; Xu, X.; Wu, P.; Shen, Y.; Zheng, B.; Huo, F.; Wei, W.D. Ultrathin 2D Cu-Porphyrin MOF Nanosheets as a Heterogeneous Catalyst for Styrene Oxidation. Mater. Chem. Front. 2019, 3, 1580-1585. [CrossRef]

50. Nakagaki, S.; Ferreira, G.; Ucoski, G.; Dias de Freitas Castro, K. Chemical Reactions Catalyzed by Metalloporphyrin-Based Metal-Organic Frameworks. Molecules 2013, 18, 7279. [CrossRef] [PubMed]

51. Smithenry, D.W.; Wilson, S.R.; Suslick, K.S. A Robust Microporous Zinc Porphyrin Framework Solid. Inorg. Chem. 2003, 42, 7719-7721. [CrossRef]

52. Castro, K.A.D.; Figueira, F.; Mendes, R.F.; Cavaleiro, J.A.S.; Neves, M.d.G.P.M.; Simões, M.M.Q.; Almeida Paz, F.A.; Tomé, J.P.C.; Nakagaki, S. Copper-Porphyrin-Metal-Organic Frameworks as Oxidative Heterogeneous Catalysts. ChemCatChem 2017, 9 , 2939-2945. [CrossRef]

53. Fateeva, A.; Chater, P.A.; Ireland, C.P.; Tahir, A.A.; Khimyak, Y.Z.; Wiper, P.V.; Darwent, J.R.; Rosseinsky, M.J. A Water-Stable Porphyrin-Based Metal-Organic Framework Active for Visible-Light Photocatalysis. Angew. Chem. Int. Ed. 2012, 51, 7440-7444. [CrossRef] [PubMed]

54. Luo, F.; Che, Y.; Zheng, J. Construction of Microporous Metal-Organic Frameworks (MOFs) by Mn-O-C Rod-like Secondary Building Units (SBUs): Solvothermal Synthesis, Structure, Thermostability, and Magnetic Properties. Inorg. Chem. Commun. 2008, 11, 358-362. [CrossRef]

55. Xiao, Q.; Wu, Y.; Li, M.; O'Keeffe, M.; Li, D. A Metal-Organic Framework with Rod Secondary Building Unit Based on the Boerdijk-Coxeter Helix. Chem. Commun. 2016, 52, 11543-11546. [CrossRef]

56. Rosi, N.L.; Kim, J.; Eddaoudi, M.; Chen, B.; O'Keeffe, M.; Yaghi, O.M. Rod Packings and Metal-Organic Frameworks Constructed from Rod-Shaped Secondary Building Units. J. Am. Chem. Soc. 2005, 127, 1504-1518. [CrossRef]

57. Rosi, N.L.; Eddaoudi, M.; Kim, J.; O'Keeffe, M.; Yaghi, O.M. Infinite Secondary Building Units and Forbidden Catenation in Metal-Organic Frameworks. Angew. Chem. Int. Ed. 2002, 41, 284-287. [CrossRef]

58. Barthelet, K.; Marrot, J.; Riou, D.; Férey, G. A Breathing Hybrid Organic-Inorganic Solid with Very Large Pores and High Magnetic Characteristics. Angew. Chem. Int. Ed. 2002, 41, 281-284. [CrossRef]

59. Shen, J.-R. The Structure of Photosystem II and the Mechanism of Water Oxidation in Photosynthesis. Annu. Rev. Plant Biol. 2015, 66, 23-48. [CrossRef] [PubMed]

60. Senge, M.O.; Ryan, A.A.; Letchford, K.A.; MacGowan, S.A.; Mielke, T. Chlorophylls, Symmetry, Chirality, and Photosynthesis. Symmetry 2014, 6, 781-843. [CrossRef]

61. Chen, D.; Xing, H.; Su, Z.; Wang, C. Electrical Conductivity and Electroluminescence of a New Anthracene-Based Metal-Organic Framework with $\pi$-Conjugated Zigzag Chains. Chem. Commun. 2016, 52, 2019-2022. [CrossRef] [PubMed]

62. Gutzler, R.; Perepichka, D.F. $\pi$-Electron Conjugation in Two Dimensions. J. Am. Chem. Soc. 2013, 135, 16585-16594. [CrossRef] [PubMed]

63. Xie, L.S.; Dincă, M. Novel Topology in Semiconducting Tetrathiafulvalene Lanthanide Metal-Organic Frameworks. Isr. J. Chem. 2018, 58, 1119-1122. [CrossRef]

64. Xie, L.S.; Alexandrov, E.V.; Skorupskii, G.; Proserpio, D.M.; Dincă, M. Diverse $\pi-\pi$ Stacking Motifs Modulate Electrical Conductivity in Tetrathiafulvalene-Based Metal-Organic Frameworks. Chem. Sci. 2019, 10, 8558-8565. [CrossRef]

65. Narayan, T.C.; Miyakai, T.; Seki, S.; Dincă, M. High Charge Mobility in a Tetrathiafulvalene-Based Microporous Metal-Organic Framework. J. Am. Chem. Soc. 2012, 134, 12932-12935. [CrossRef]

66. Li, W.-J.; Tu, M.; Cao, R.; Fischer, R.A. Metal-Organic Framework Thin Films: Electrochemical Fabrication Techniques and Corresponding Applications \& Perspectives. J. Mater. Chem. A 2016, 4, 12356-12369. [CrossRef]

67. Jiang, C.; Moniz, S.J.A.; Wang, A.; Zhang, T.; Tang, J. Photoelectrochemical Devices for Solar Water Splitting-Materials and Challenges. Chem. Soc. Rev. 2017, 46, 4645-4660. [CrossRef]

68. Duan, J.; Chen, S.; Zhao, C. Ultrathin Metal-Organic Framework Array for Efficient Electrocatalytic Water Splitting. Nat. Commun. 2017, 8, 15341. [CrossRef]

69. Haldar, R.; Jakoby, M.; Mazel, A.; Zhang, Q.; Welle, A.; Mohamed, T.; Krolla, P.; Wenzel, W.; Diring, S.; Odobel, F.; et al. Anisotropic Energy Transfer in Crystalline Chromophore Assemblies. Nat. Commun. 2018, 9, 4332. [CrossRef]

70. Zeng, K.; Tong, Z.; Ma, L.; Zhu, W.-H.; Wu, W.; Xie, Y. Molecular engineering strategies for fabricating efficient porphyrin-based dye-sensitized solar cells. Energy Environ. Sci. 2020, 13, 1617-1657. [CrossRef]

71. Zeng, K.; Chen, Y.; Zhu, W.-Y.; Tian, H.; Xie, Y. Efficient Solar Cells Based on Concerted Companion Dyes Containing Two Complementary Components: An Alternative Approach for Cosensitization. J. Am. Chem. Soc. 2020, 142, 5154-5161. [CrossRef] 
72. Zou, J.; Yan, Q.; Li, C.; Lu, Y.; Tong, Z.; Xie, Y. Light-Absorbing Pyridine Derivative as a New Electrolyte Additive for Developing Efficient Porphyrin Dye-Sensitized Solar Cells. ACS Appl. Mater. Interfaces 2020, 12, 57017-57024. [CrossRef]

73. Kurumisawa, Y.; Higashino, T.; Nimura, S.; Tsuji, Y.; Iiyama, Y.; Imahori, Y. Renaissance of Fused Porphyrins: Substituted Methylene-Bridged Thiophene-Fused Strategy for High-Performance Dye-Sensitized Solar Cells. J. Am. Chem. Soc. 2019, 141, 9910-9919. [CrossRef]

74. Li, C.; Yin, J.; Chen, R.; Lv, X.; Feng, X.; Wu, Y.; Cao, J. Monoammonium Porphyrin for Blade-Coating Stable Large-Area Perovskite Solar Cells with $>18 \%$ Efficiency. J. Am. Chem. Soc. 2019, 141, 6345-6351. [CrossRef] [PubMed]

75. Zha, Q.; Rui, X.; Wei, T.; Xie, Y. Recent advances in the design strategies for porphyrin-based coordination polymers. CrystEngComm. 2014, 16, 7371-7384. [CrossRef]

76. Lu, W.; Wei, Z.; Gu, Z.-Y.; Liu, T.-F.; Park, J.; Park, J.; Tian, J.; Zhang, M.; Zhang, Q.; Gentle, T., III; et al. Tuning the Structure and Function of Metal-Organic Frameworks via Linker Design. Chem. Soc. Rev. 2014, 43, 5561-5593. [CrossRef] [PubMed]

77. Schoedel, A.; Li, M.; Li, D.; O'Keeffe, M.; Yaghi, O.M. Structures of Metal-Organic Frameworks with Rod Secondary Building Units. Chem. Rev. 2016, 116, 12466-12535. [CrossRef]

78. Fang, Q.-R.; Zhu, G.-S.; Jin, Z.; Ji, Y.-Y.; Ye, J.-W.; Xue, M.; Yang, H.; Wang, Y.; Qiu, S.-L. Mesoporous Metal-Organic Framework with Rare Etb Topology for Hydrogen Storage and Dye Assembly. Angew. Chem. Int. Ed. 2007, 46, 6638-6642. [CrossRef] [PubMed]

79. Sun, Y.; Zhou, H.-C. Recent Progress in the Synthesis of Metal-Organic Frameworks. Sci. Technol. Adv. Mater. 2015, 16, 54202. [CrossRef] [PubMed]

80. Lu, K.; He, C.; Lin, W. Nanoscale Metal-Organic Framework for Highly Effective Photodynamic Therapy of Resistant Head and Neck Cancer. J. Am. Chem. Soc. 2014, 136, 16712-16715. [CrossRef]

81. Verduzco, J.M.; Chung, H.; Hu, C.; Choe, W. Metal-Organic Framework Assembled from T-Shaped and Octahedral Nodes: A Mixed-Linker Strategy to Create a Rare Anatase $\mathrm{TiO}_{2}$ Topology. Inorg. Chem. 2009, 48, 9060-9062. [CrossRef]

82. Görbitz, C.H. The Development and Use of a Crystallographic Database. Acta Cryst. 2016, B72, 167-168. [CrossRef]

83. Adler, A.D.; Longo, F.R.; Kampas, F.; Kim, J. On the Preparation of Metalloporphyrins. J. Inorg. Nucl. Chem. 1970, 32, $2443-2445$. [CrossRef]

84. Johnson, J.A.; Luo, J.; Zhang, X.; Chen, Y.-S.; Morton, M.D.; Echeverría, E.; Torres, F.E.; Zhang, J. Porphyrin-Metalation-Mediated Tuning of Photoredox Catalytic Properties in Metal-Organic Frameworks. ACS Catal. 2015, 5, 5283-5291. [CrossRef]

85. Chen, H.-C.; Reek, J.N.H.; Williams, R.M.; Brouwer, A.M. Halogenated Earth Abundant Metalloporphyrins as Photostable Sensitizers for Visible-Light-Driven Water Oxidation in a Neutral Phosphate Buffer Solution. Phys. Chem. Chem. Phys. 2016, 18, 15191-15198. [CrossRef] [PubMed]

86. Liu, Y.; Han, Y.; Zhang, Z.; Zhang, W.; Lai, W.; Wang, Y.; Cao, R. Low Overpotential Water Oxidation at Neutral PH Catalyzed by a Copper(ii) Porphyrin. Chem. Sci. 2019, 10, 2613-2622. [CrossRef] [PubMed]

87. Uranga, J.; Matxain, J.M.; Lopez, X.; Ugalde, J.M.; Casanova, D. Photosensitization Mechanism of Cu(ii) Porphyrins. Phys. Chem. Chem. Phys. 2017, 19, 20533-20540. [CrossRef]

88. Wang, D.; Astruc, D. The Recent Development of Efficient Earth-Abundant Transition-Metal Nanocatalysts. Chem. Soc. Rev. 2017, 46, 816-854. [CrossRef] [PubMed]

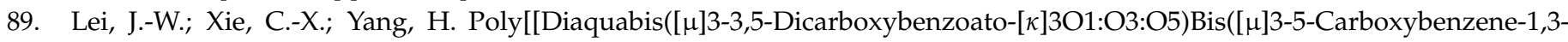
Dicarboxylato- $[\kappa] 3 \mathrm{O}_{1}: \mathrm{O}_{3}: \mathrm{O}_{5}$ ) Tetrakis(Methylformamide-[ $\left.[\kappa] \mathrm{O}\right)$ Trimanganese(II)] Dimethylformamide Tetrasolvate]. Acta Cryst. 2012, E68, 697-698. [CrossRef]

90. Mondal, K.C.; Sengupta, O.; Nethaji, M.; Mukherjee, P.S. Assembling Metals (Co ${ }^{\mathrm{II}}$ and $\mathrm{Mn}^{\mathrm{II}}$ ) with Pyridylcarboxylates in the Presence of Azide: Synthesis, Structural Aspects and Magnetic Behavior of Three Coordination Polymers. Dalton Trans. 2008, 767-775. [CrossRef]

91. Deenadayalan, M.S.; Sharma, N.; Verma, P.K.; Nagaraja, C.M. Visible-Light-Assisted Photocatalytic Reduction of Nitroaromatics by Recyclable Ni(II)-Porphyrin Metal-Organic Framework (MOF) at RT. Inorg. Chem. 2016, 55, 5320-5327. [CrossRef]

92. Hunter, C.A.; Sanders, J.K.M. The Nature of $\pi-\pi$ Interactions. J. Am. Chem. Soc. 1990, 112, 5525-5534. [CrossRef]

93. Kingsbury, C.J.; Senge, M.O. The Shape of Porphyrins. Coord. Chem. Rev. 2021, 431, 213760. [CrossRef]

94. Macrae, C.F.; Edgington, P.R.; McCabe, P.; Pidcock, E.; Shields, G.P.; Taylor, R.; Towler, M.; van de Streek, J. Mercury: Visualization and Analysis of Crystal Structures. J. Appl. Cryst. 2006, 39, 453-457. [CrossRef]

95. Spek, A.L. PLATON SQUEEZE: A Tool for the Calculation of the Disordered Solvent Contribution to the Calculated Structure Factors. Acta Cryst. 2015, C71, 9-18. [CrossRef]

96. Gutschke, S.O.H.; Price, D.J.; Powell, A.K.; Wood, P.T. Hydrothermal Synthesis, Structure, and Magnetism of $[\mathrm{Co} 2(\mathrm{OH})\{1,2,3-$ $\left.\left.\left(\mathrm{O}_{2} \mathrm{C}\right) 3 \mathrm{C}_{6} \mathrm{H}_{3}\right\}\left(\mathrm{H}_{2} \mathrm{O}\right)\right] \cdot \mathrm{H}_{2} \mathrm{O}$ and $\left[\mathrm{Co}_{2}(\mathrm{OH})\left\{1,2,3-\left(\mathrm{O}_{2} \mathrm{C}\right) 3 \mathrm{C}_{6} \mathrm{H}_{3}\right\}\right]$ : Magnetic $\Delta$-Chains with Mixed Cobalt Geometries. Angew. Chem. Int. Ed. 2001, 40, 1920-1923. [CrossRef]

97. Wang, X.-W.; Chen, Y.; Chen, J.-Z.; Liu, J.-H.; Han, L. Structure and Stability of a Linear Trinuclear Cobalt(II) Complex: $\mathrm{Co}_{3}\left(\mathrm{PhCH}=\mathrm{CHCO}_{2}\right) 6($ Bpy $)$ 2. Z. Naturforschung 2008, 63, 129-133. [CrossRef]

98. Jiang, W.-H.; Zhang, H.-Z.; Hou, G.-F.; Ma, D.-S.; Liu, B.; Yu, Y.-H. Five Co(ii) Coordination Polymers with Different Counter Anions Based on [3,5-Di(4H-1,2,4-Triazol-4-Yl)Benzoato]—Ligand: Directed Synthesis, Structures and Magnetic Properties. RSC Adv. 2017, 7, 45641-45651. [CrossRef] 
99. Pratik, S.M.; Gagliardi, L.; Cramer, C.J. Boosting Photoelectric Conductivity in Porphyrin-Based MOFs Incorporating C60. J. Phys. Chem. C 2020, 124, 1878-1887. [CrossRef]

100. Liu, J.; Zhou, W.; Liu, J.; Fujimori, Y.; Higashino, T.; Imahori, H.; Jiang, X.; Zhao, J.; Sakurai, T.; Hattori, Y.; et al. A New Class of Epitaxial Porphyrin Metal-Organic Framework Thin Films with Extremely High Photocarrier Generation Efficiency: Promising Materials for All-Solid-State Solar Cells. J. Mater. Chem. A 2016, 4, 12739-12747. [CrossRef]

101. Morzyk-Ociepa, B.; Kokot, M.; Różycka-Sokołowska, E.; Giełzak-Koćwin, K.; Filip-Psurska, B.; Wietrzyk, J.; Michalska, D. Crystal Structure, Infrared and EPR Spectra and Anticancer Activity in Vitro of the Novel Manganese(II) Complexes of Indolecarboxylic Acids. Polyhedron 2014, 67, 464-470. [CrossRef]

102. Boucher, L.J.; Katz, J.J. The Infared Spectra of Metalloporphyrins. J. Am. Chem. Soc. 1967, 89, 1340-1345. [CrossRef] [PubMed]

103. Shundalau, M.B.; Komyak, A.I.; Zazhogin, A.P.; Umreiko, D.S. Structure of the Complex $\mathrm{UCl}_{4} \cdot 2 \mathrm{DMF}$ by Vibrational Infrared Spectroscopy and Density Functional Theory. J. Appl. Spectrosc. 2012, 79, 22-30. [CrossRef]

104. Bruker. Bruker SMART; Version 5.629, 1997-2003; Bruker-Axs Inc: Madison, WI, USA, 2003.

105. Bruker. Bruker Saint-Plus; Version 6.22, 1997-2003; Bruker-Axs Inc: Madison, WI, USA, 2003.

106. Sheldrick, G.M. SHELXTL; Version 5.1, 1998; Bruker Axs-Inc: Madison, WI, USA, 1998.

107. Laha, J.K.; Dhanalekshmi, S.; Taniguchi, M.; Ambroise, A.; Lindsey, J.S. A Scalable Synthesis of Meso-Substituted Dipyrromethanes. Org. Process. Res. Dev. 2003, 7, 799-812. [CrossRef]

108. Meindl, A.; Ryan, A.; Flanagan, K.; Senge, M. Synthesis of Long-Wavelength Absorbing Porphyrin m-Benzoic Acids as Molecular Tectons for Surface Studies. Heterocycles 2017, 94, 1518-1541. [CrossRef]

109. Landrou, G.; Panagiotopoulos, A.A.; Ladomenou, K.; Coutsolelos, A.G. Photochemical Hydrogen Evolution Using Sn-Porphyrin as Photosensitizer and a Series of Cobaloximes as Catalysts. J. Porphyr. Phthalocyanines 2016, 20, 534-541. [CrossRef] 